\title{
Neurotrophic factor small-molecule mimetics mediated neuroregeneration and synaptic repair: emerging therapeutic modality for Alzheimer's disease
}

Syed Faraz Kazim ${ }^{1,2}$ and Khalid |qbal $\left.\right|^{*}$

\begin{abstract}
Alzheimer's disease (AD) is an incurable and debilitating chronic progressive neurodegenerative disorder which is the leading cause of dementia worldwide. $A D$ is a heterogeneous and multifactorial disorder, histopathologically characterized by the presence of amyloid $\beta(A \beta)$ plaques and neurofibrillary tangles composed of $A \beta$ peptides and abnormally hyperphosphorylated tau protein, respectively. Independent of the various etiopathogenic mechanisms, neurodegeneration is a final common outcome of AD neuropathology. Synaptic loss is a better correlate of cognitive impairment in $A D$ than $A \beta$ or tau pathologies. Thus a highly promising therapeutic strategy for $A D$ is to shift the balance from neurodegeneration to neuroregeneration and synaptic repair. Neurotrophic factors, by virtue of their neurogenic and neurotrophic activities, have potential for the treatment of AD. However, the clinical therapeutic usage of recombinant neurotrophic factors is limited because of the insurmountable hurdles of unfavorable pharmacokinetic properties, poor blood-brain barrier (BBB) permeability, and severe adverse effects. Neurotrophic factor small-molecule mimetics, in this context, represent a potential strategy to overcome these short comings, and have shown promise in preclinical studies. Neurotrophic factor small-molecule mimetics have been the focus of intense research in recent years for $A D$ drug development. Here, we review the relevant literature regarding the therapeutic beneficial effect of neurotrophic factors in $A D$, and then discuss the recent status of research regarding the neurotrophic factor small-molecule mimetics as therapeutic candidates for AD. Lastly, we summarize the preclinical studies with a ciliary neurotrophic factor (CNTF) small-molecule peptide mimetic, Peptide 021 (P021). P021 is a neurogenic and neurotrophic compound which enhances dentate gyrus neurogenesis and memory processes via inhibiting leukemia inhibitory factor (LIF) signaling pathway and increasing brain-derived neurotrophic factor (BDNF) expression. It robustly inhibits tau abnormal hyperphosphorylation via increased BDNF

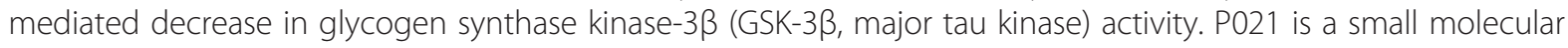
weight, BBB permeable compound with suitable pharmacokinetics for oral administration, and without adverse effects associated with native CNTF or BDNF molecule. P021 has shown beneficial therapeutic effect in several preclinical studies and has emerged as a highly promising compound for AD drug development.
\end{abstract}

Keywords: Alzheimer's disease, Cognition, Neurotrophic factor small-molecule mimetics, Brain-derived neurotrophic factor (BDNF), Ciliary neurotrophic factor (CNTF), Amyloid beta, Tau, Neurogenesis, Synaptic loss, Neurodegeneration

\footnotetext{
* Correspondence: khalid.iqbal.ibr@gmail.com

'Department of Neurochemistry, and SUNY Downstate/NYSIBR Program in

Developmental Neuroscience, New York State Institute for Basic Research

(NYSIBR), 1050 Forest Hill Road, Staten Island, NY 10314, USA

Full list of author information is available at the end of the article
} 


\section{Background}

Alzheimer's disease (AD) is a chronic, debilitating, neurodegenerative disorder and is the most common form of dementia in the elderly $[1,2]$. AD is the sixth leading cause of mortality in the United States, and affects nearly 5.4 million Americans [3, 4]. Approximately 476,000 people age 65 or older are expected to develop AD in the United States in the year 2016, and the total healthcare expenditure for $\mathrm{AD}$ and related dementias will be nearly 236 billion dollars, making it one of the costliest chronic diseases in the United States [4]. Worldwide, AD and related dementias affect approximately 47 million people [5]. As yet there is no effective cure for AD [6]. By the year 2050, the prevalence of $\mathrm{AD}$ is projected to be 13.8 million in United States [3, 7], and 135 million worldwide [5, 8], lest an effective AD therapy is developed.

$\mathrm{AD}$ is clinically characterized by a heterogeneous set of symptoms including progressive memory impairment, visuospatial decline, aphasia, and loss of executive function [1, 9-11]. Short-term memory loss is the most common early symptom of AD [1, 9-11]. Histopathologically, there are two major lesions in AD: senile plaques (diffuse and neuritic) and neurofibrillary tangles (NFTs) $[12,13]$. Amyloid $\beta(A \beta)$ is the main component of the senile plaques whereas abnormally hyperphosphorylated tau protein gives rise to NFTs [12, 13]. Alongside $A \beta$ plaques and NFTs, impairments in adult hippocampal neurogenesis and synaptic plasticity, synaptic deficit, and profound neurodegeneration are also major features of AD [14-25]. Adult hippocampal neurogenesis and synaptic plasticity have been proposed to be essential for learning and memory [26-30]. Alterations in adult hippocampal neurogenesis and synaptic plasticity could thus be the major mechanisms underlying cognitive dysfunction in $\mathrm{AD}[18,31]$. AD has also been characterized as a consequence of synaptic failure [22, 32]. Several studies have shown that synaptic loss correlates better with cognitive decline than either $A \beta$ plaque load or NFTs [25, 33-35]. Targeting the impairment in adult hippocampal neurogenesis and neuronal and synaptic loss has been proposed as a potential therapeutic approach to rescue cognitive dysfunction in $\mathrm{AD}[6,36]$.

\section{Main text}

\section{Etiopathogenesis of Alzheimer's disease}

$\mathrm{AD}$, first described by German psychiatrist Alois Alzheimer in 1907 [37], is a multifactorial and heterogeneous disease, and apparently involves several different etiopathogenic mechanisms (Fig. 1) [6, 38]. The early-onset familial form of $\mathrm{AD}$ which is caused by mutations in amyloid $\beta$ precursor protein (APP), presenilin 1 (PS1), or presenilin 2 (PS2), accounts for $<1 \%$ of all cases (Fig. 1) (for review, [39, 40]). The exact causes of the late-onset sporadic form of $\mathrm{AD}$, which accounts for over $99 \%$ of the cases, are not yet

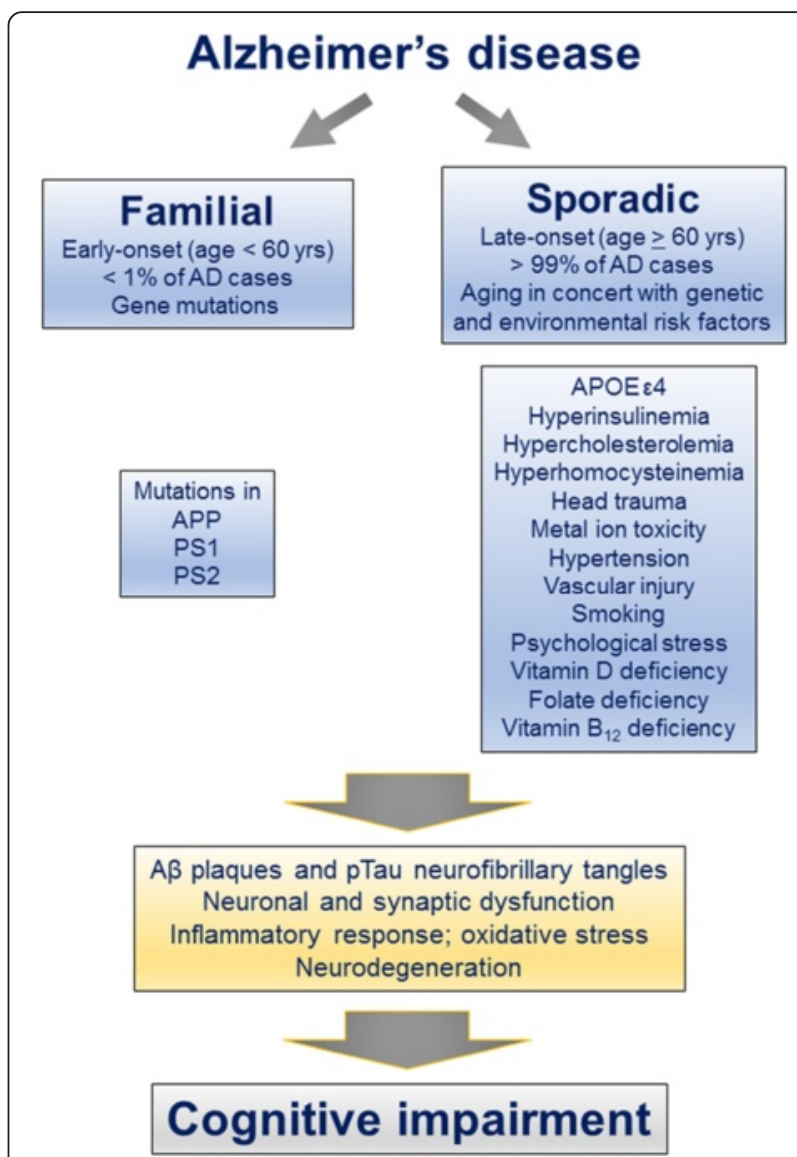

Fig. 1 Multifactorial nature of AD and involvement of several different etiopathogenic mechanisms. Early-onset familial AD caused by mutations in APP, PS1, or PS2 constitutes $<1 \%$ of AD cases. The exact causes of late-onset sporadic AD which accounts for the remaining $>99 \%$ of $A D$ cases are as yet largely unknown. However, aging alongside gene-environment interaction is speculated to contribute to this form of AD. Both forms of AD lead to amyloid plaque and neurofibrillary pathologies, synaptic dysfunction and neurodegeneration, and ultimately cognitive impairment

understood. The sporadic form of AD probably involves several different etiopathogenic mechanisms in concert with aging such as metabolic derangements, head trauma, metal ion toxicity, hypertension, vascular injury, smoking, psychological stress, and vitamin deficiencies (Fig. 1) [38]. No known mutations are involved in sporadic form of $\mathrm{AD}$, however, the presence of one or two apolipoprotein $\mathrm{E}$ epsilon 4 (APOE $\varepsilon 4$ ) alleles increases the disease risk $\sim 3.5$-fold or $\sim 10$-fold, respectively [39-41].

The histopathological hallmarks in both the sporadic and the familial forms of $\mathrm{AD}$ are similar and include amyloid $\beta$ plaques and NFTs leading to neurodegeneration (Fig. 2) [6]. The immensely popular amyloid cascade hypothesis suggests a major etiological role of $A \beta$ for the NFT pathology, neurodegeneration and cognitive dysfunction in $\mathrm{AD}$ [42]. $\mathrm{A} \beta$ plaques are produced by amyloidogenic processing of the transmembrane protein, APP, by 


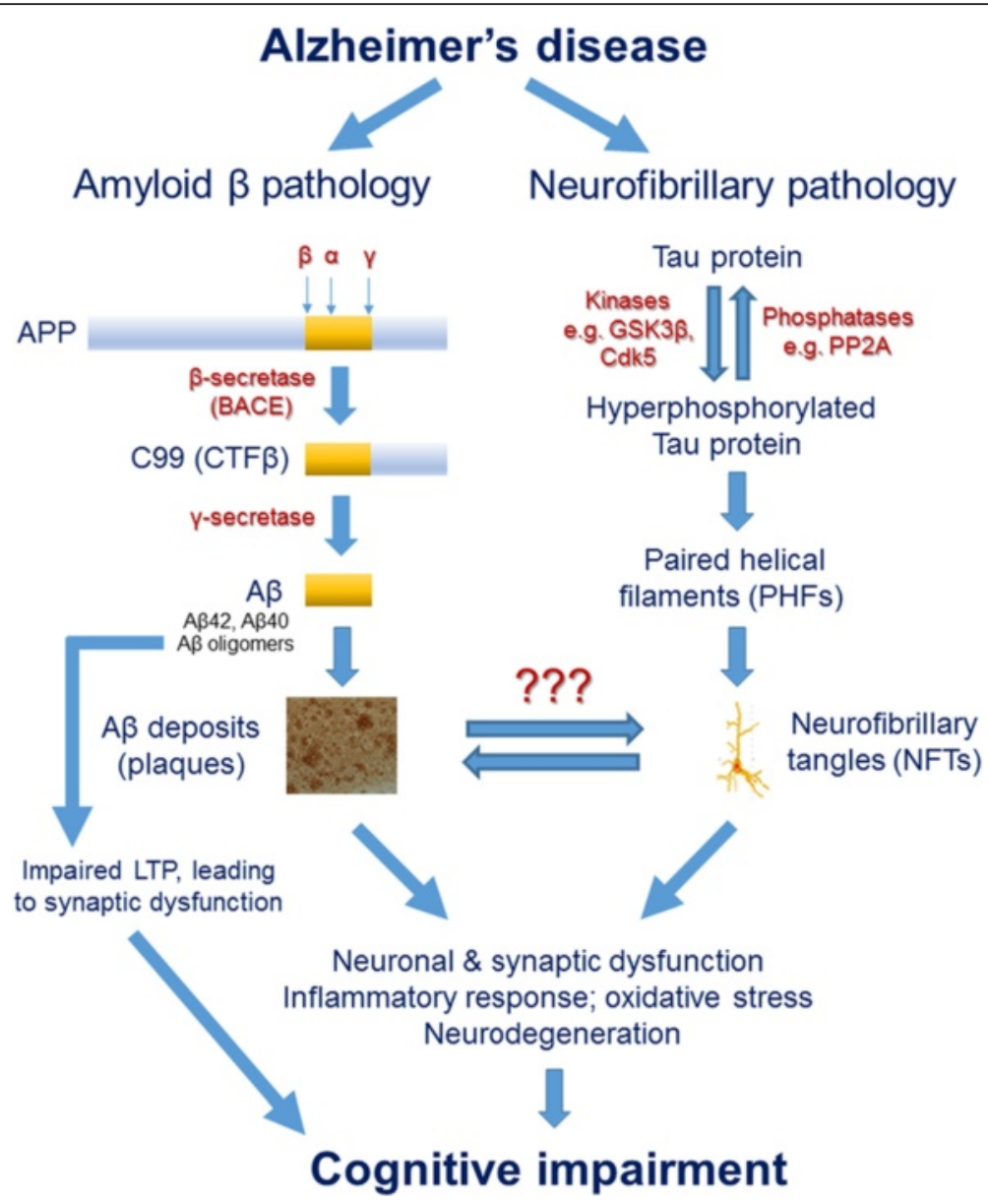

Fig. $2 A \beta$ plaques and NFTs as hallmarks of AD. AD is characterized by extracellular deposits of A (senile) plaques and intraneuronal NFTs leading to neurodegeneration, and ultimately cognitive impairment and dementia. A $\beta$ plaques are produced by the amyloidogenic processing of APP by $\beta$ - and $\gamma$-secretase enzymes leading to the formation of $A \beta$ peptides (36-43 amino acids) of which the $A \beta 40$ and $A \beta 42$ are the most common. $A \beta 42$ is the most fibrillogenic and thus most amyloidogenic A $\beta$ peptide. A $\beta$ oligomers impair hippocampal LTP, and thus synaptic plasticity, and learning and memory. NFTs are intracellular aggregates of MAP-tau which is abnormally hyperphosphorylated by upregulation of activities of kinases such as GSK3 $\beta$ and Cdk5 or deficit in phosphatases such as PP2A

$\beta$ - and $\gamma$-secretase enzymes resulting in the formation of major toxic products, $A \beta 40$ and $A \beta 42$ peptides (Fig. 2) $[12,43,44]$. The oligomeric form of $A \beta$ has also been suggested as the main neurotoxic state of the peptide [45]. A $\beta$ oligomers are known to inhibit hippocampal long-term potentiation (LTP) [46], a major cellular mechanism underlying synaptic plasticity, and learning and memory [47]. Amyloid cascade hypothesis also derives its major support from the Down syndrome individuals; as part of the trisomy 21, these patients carry 3 copies of APP and almost all of them develop AD neuropathological characteristics by the age of 40 years $[48,49]$.

Tau which is a neuronal microtubule associated protein (MAP) is a major protein subunit of paired helical filaments that constitute the NFTs (Fig. 2) [50, 51]. Tau in NFTs is abnormally hyperphosphorylated [13]. Tau is a substrate for several protein kinases including cyclindependent kinase 5 (Cdk5), glycogen synthase kinase 3 $\beta$ (GSK-3 3 ), and calcium/calmodulin activated protein kinase II (CaMKII) [52, 53]. The activities of several major tau kinases are regulated by protein phosphatase 2A (PP2A). PP2A can thus regulate the tau phosphorylaiton both directly and by inhibiting the activities of tau protein kinases [54]. PP2A activity is impaired and is possibly a cause of the abnormal hyperphosphorylation of tau in AD brain [55-57].

\section{Stages of Alzheimer's disease}

The neuropathologic staging of $\mathrm{AD}$ is performed based on three parameters $(\mathrm{A} \beta$, Braak, and Consortium to Establish a Registry for $\mathrm{AD}, \mathrm{CERAD)}$ to obtain an "ABC" score: histopathologic assessments of $A \beta$-containing amyloid plaques (A), Braak staging of NFTs (B), and scoring of neuritic amyloid plaques (C). The NFT load in AD brain are known to correlate better with cognitive decline [58]. In the earliest stages of $\mathrm{AD}$ (Braak stage I-II, prodromal 
AD), NFTs are confined to the entorhinal cortex $[59,60]$. Subsequently, NFTs spread to the limbic and medial temporal lobe (Braak stage III-IV; mild cognitive impairment, $\mathrm{MCI}$, or early AD); this stage correlates with early memory related symptoms in $\mathrm{AD}[61,62]$. During the late stages (Braak stage V-VI, clinical AD), the number of NFTs increase and they occur in neocortical areas leading to impairments in higher cognitive functions such as executive and visuospatial abilities, and speech in concert with AD-related cognitive deficits [60,63].

$\mathrm{AD}$ is a progressive neurodegenerative disorder (Fig. 3). As mentioned before, the earliest neuropathological changes in $\mathrm{AD}$ are in the hippocampus and entorhinal cortex, followed by changes in the medial temporal lobe [64-68]. Correspondingly, the earliest detectable cognitive deficit is in the medial temporal lobe dependent episodic memory $[62,69,70]$. Episodic memory deficits are followed by impairment in semantic memory; both memory domains depend on the neural circuitry of medial and lateral temporal lobes and occur prior to deficit in higher cognitive functions such as attention, and executive and visuospatial capabilities [71]. Mild deficits in executive functioning are first detectable near the end of the preclinical phase of $\operatorname{AD}[72,73]$. As the patient progresses from preclinical stage of $\mathrm{AD}$ into $\mathrm{MCI}$, more cognitive functions begin to be impaired including verbal recall and deterioration of general memory domain $[71,74]$. As the patient progresses from MCI into mild, moderate, and subsequently the severe stages of $\mathrm{AD}$, general cognition continues to decline with impairment manifesting in all cognitive domains [75].

\section{Neurogenic and synaptic failure in Alzheimer's disease}

Adult hippocampal neurogenesis plays a pivotal role in learning and memory $[26-28,30,76]$. The essential role of adult-born hippocampal neurons has been suggested in complex forms of spatial and associative memory [27, 77-81]. In rodents, the aberrant hippocampal neurogenesis leads to impairment in different forms of hippocampus dependent learning such as in Morris water maze and contextual fear conditioning tasks [82, 83]. AD and other neurodegenerative diseases are characterized by an imbalance between neurogenesis and neurodegeneration [18, 84]. Consequently, the impairment in neurogenesis has been hypothesized to contribute to learning and memory deficits in $\operatorname{AD}[17,18,84]$.

In adult hippocampus, the survival, maturation, and integration of new born neurons in the dentate gyrus depends on the appropriate brain milieu or microenvironment primarily provided by the neurotrophic factors [85-89]. The dentate gyrus microenvironment in neurodegenerative conditions such as $\mathrm{AD}$ is not conducive for the neurogenesis and the survival, maturation, and integration of new born neurons into the hippocampal

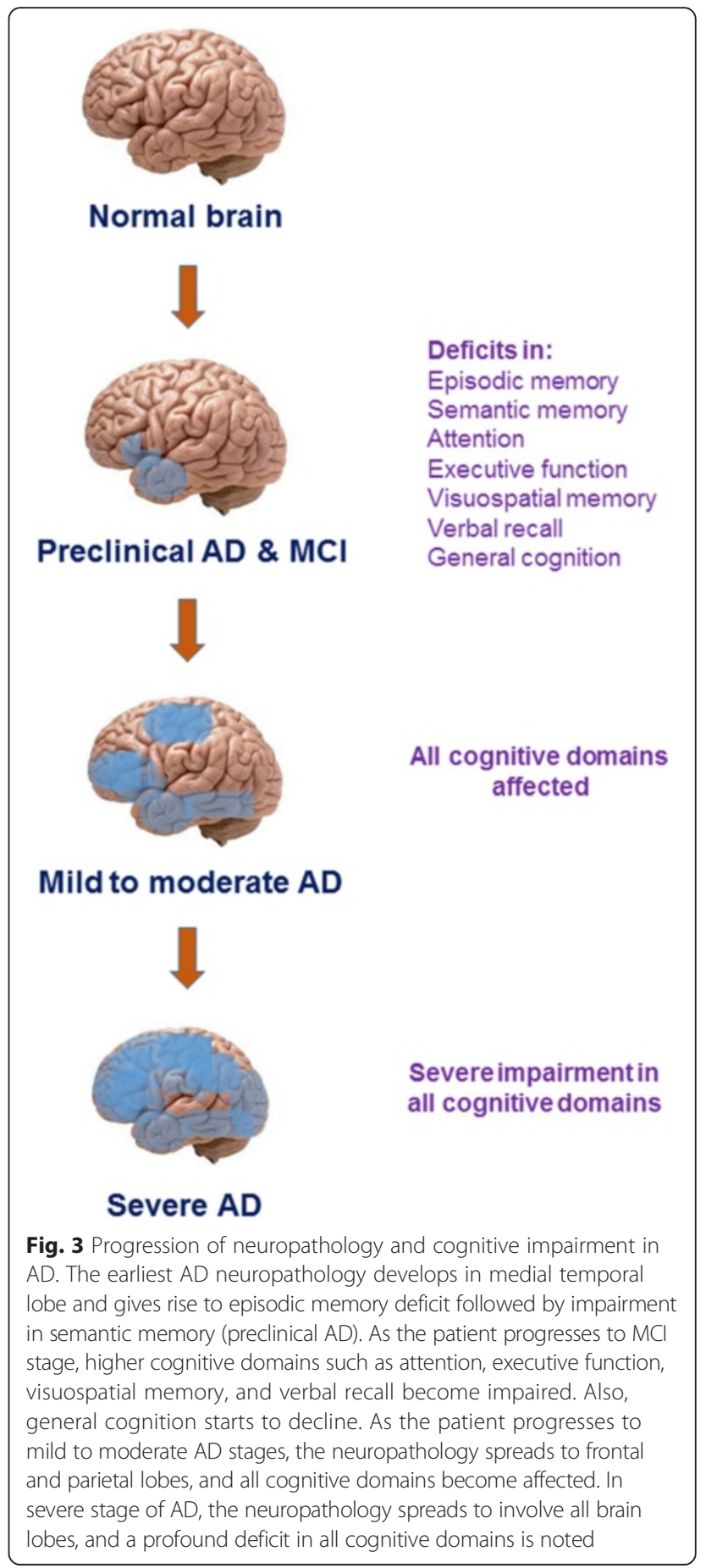

functional circuitry [90-92]. The AD brain responds to neurodegeneration by stimulating neurogenesis, however, because of the lack of a proper neurotrophic microenvironment of the hippocampus, this effort of the AD brain to replace lost neurons with new neurons is unsuccessful and culminates in failure of neuronal survival, maturation, and integration $[16,17,36,93]$. As the disease progresses, 
the neurogenic failure becomes severe, and contributes significantly to cognitive decline $[18,36]$.

$\mathrm{AD}$ has been described as a synaptic failure [22, 32]. AD brains also show dendritic and dendritic spine loss [94]. Quantitative studies on AD brains within 2-4 years after the clinically diagnosed disease showed a $25-35 \%$ decrease in synaptic density and a 15-35 \% synaptic loss per neuron in the frontal and temporal lobes of the cerebral cortex [15]. The extent of synaptic loss is even more severe in the hippocampus where it amounts to $44-55 \%[19-21,95,96]$. Remarkably, the synaptic loss in frontal cortex and limbic system is the best correlate of the severity of cognitive dysfunction [25, 33-35]. The profound neuronal, synaptic, and dendritic loss may contribute to impaired synaptic plasticity, including reduced LTP, in AD. Synaptic plasticity is known to be the cellular substrate of learning and memory [29]. Additionally, adult hippocampal neurogenesis has been proposed to play a pivotal role in synaptic plasticity, and subsequently, learning and memory processes in the hippocampus [97]. Both human $\mathrm{AD}$ cases and $\mathrm{AD}$ transgenic mice exhibit significant alterations in the process of adult hippocampal neurogenesis [16, 93, 98-104]. The synaptic plasticity impairments in AD, thus, may not only be the consequence of synaptic failure but also impaired neurogenesis.

\section{Shifting the balance from neurodegeneration to neural regeneration to treat Alzheimer's disease}

The final common outcome of various different etiopathogenic mechanisms involved in $\mathrm{AD}$ is neurodegeneration leading to cognitive impairment. Thus, a highly promising therapeutic strategy for $\mathrm{AD}$ is to shift the balance from neurodegeneration to neural regeneration $[6,36]$. This can be achieved by utilizing means that can enhance adult hippocampal neurogenesis and neuronal and synaptic plasticity. Several different approaches have been employed in rodent models of AD with reasonable success to enhance neurogenesis and neuronal and synaptic plasticity [105]. Neural stem cells-based replacement approach for AD is currently the focus of intense research and has shown promising results in animal models of AD [106, 107]. Neural stem cell implantation in the triple transgenic $\mathrm{AD}$ mice (3xTg-AD) that harbor mutated human APP, tau, and PS1, has been reported to rescue cognitive impairment via increased brain derived neurotrophic factor (BDNF) expression [108]. Pharmacological stimulation of neural stem cells with neurotrophic factors and growth factors such as fibroblast growth factor 2 (FGF2) [109], BDNF [110], ciliary neurotrophic factor (CNTF) [111] has also shown promise in mouse models of AD.

\section{Neurotrophic factors - potent neuronal and synaptic} repair molecules for the treatment of Alzheimer's disease Neurotrophic factors can be broadly divided into 3 families: (1) neurotrophins, (2) glial cell-line derived neurotrophic factor (GDNF) family ligands (GFLs), and (3) neuropoeitic cytokines [112]. The neuroprotective effect of various neurotrophic factors via neuroregeneration and synaptic repair is well established [110, 113, 114].

The neurotrophin family comprises nerve growth factor (NGF), BDNF, neurotrophin 3 (NT3), and neurotrophin 4 (NT4) [115]. Neurotrophin signaling is mediated via two receptor types: 775 neurotrophin receptor $\left(\mathrm{p} 75^{\mathrm{NTR}}\right)$ and tropomysin receptor kinase (Trk) [115]. Each Trk receptor selectively binds to different neurotrophins: NGF binds to TrkA, BDNF and NT4 bind to TrkB, and NT3 binds to TrkC $[112,115]$. Neurotrophin signaling occurs via several different pathways including two major tyrosine kinase-mediated pathways: the phosphoinositide 3-kinase (PI3K)-AKT (also known as protein kinase B, PKB) pathway and the mitogen-activated protein kinase (MAPK)extracellular signal-regulated kinase (ERK) pathway $[112,115]$. The neurotrophin signaling mediates neuronal survival, proliferation, and differentiation [115]. Imbalance in the neurotrophin levels in different brain regions has been shown in AD cases [116]. BDNF levels have been shown to be decreased in AD brains suggesting a lack of trophic support that may contribute significantly to neurodegeneration [116-119]. BDNF is essential for basal level of adult hippocampal neurogenesis and also for the survival and integration of new-born neurons into the hippocampal circuitry $[120,121]$. BDNF also plays a crucial role in both the early and late phases of LTP, the cellular substrate for learning and memory [122-125]. In mouse and primate models of $\mathrm{AD}$, entorhinal cortex administration of BDNF was found to have a beneficial effect on cognition [110]. In human AD cases, decreased NGF levels have been shown in the nucleus basalis of Meynert [126], a group of neurons in the basal forebrain which has wide ascending projections to the neocortex, is rich in acetylcholine (Ach) and choline acetyltransferase (ChAT), and is well known to undergo degeneration in AD [127]. In animal models, it has been demonstrated that the ascending cholinergic projections in the brain express low- and high-affinity NGF receptors and are NGF-sensitive and probably NGF-dependent $[128,129]$. Cholinergic degeneration leads to cognitive dysfunction, and treatment with NGF can improve cognition in animal models $[128,129]$. NGF gene therapy has recently been shown to exert a neurotrophic effect in AD patients [130].

The GDNF family of ligands (GFL) comprises of four neurotrophic factors: GDNF, neurturin (NRTN), artemin (ARTN), and persephin (PSPN) [131]. GFL signaling occurs through binding of a particular GFL dimer to a cell surface bound co-receptor, a member of the GFR $\alpha$ 
protein family, and subsequent activation of a receptor tyrosine kinase molecule, RET ("rearranged during transfection") [131]. The primary ligands for the co-receptors GFR $\alpha 1$, GFR $\alpha 2$, GFR $\alpha 3$, and GFR $\alpha 4$ are GDNF, NRTN, ARTN, and PSPN, respectively [131]. GFLs play a role in several different processes including neuronal survival, differentiation, and migration, and neurite outgrowth [131]. Deficiency of GFR $\alpha 1$, the receptor for GDNF, have been shown in human AD brains [132]. Also, GDNF gene therapy has been reported to protect against $\mathrm{AD}$-like neuropathology in 3xTg-AD mice [133].

Neuropoietic cytokines family of neurotrophic factors exert many similar effects including enhancing neuronal proliferation and differentiation, however, this group signals through cytokine receptors rather than receptor tyrosine kinases $[134,135]$. The transforming growth factor $\beta$ (TGF $\beta$ ) and interleukin-6 (IL-6) superfamilies are some of the most abundant and influential neuropoeitic cytokines in the brain, particularly during development $[134,135]$. The TGF $\beta$ superfamily includes brain morphogenic proteins (BMPs) which play a key role in regulating neuron induction $[134,135]$. BMPs interact with key neurogenic elements including Wnts and sonic hedgehog, and establish cell-fate determination and subtype differentiation [136-138]. The IL-6 family of cytokines includes CNTF, interleukin-11 (IL-11), leukemia inhibitory factor (LIF), oncostatin-M, cardiotrophin-1, and cardiotrophinlike cytokine $[139,140]$. CNTF plays a pivotal role in adult hippocampal and subventricular zone neurogenesis, and the differentiation of neural stem cells [141-143]. CNTF signaling occurs through a tripartite complex of CNTF receptor $\alpha(\mathrm{CNTFR} \alpha)$, LIF $\beta$ receptor (LIFR), and glycoprotein 130 (gp130). CNTF and LIF both signal through tyrosine phosphorylation (Tyr706) of the signal transducers and activators of transcription (STAT) proteins by the membrane associated Janus kinase (JAK) [144]. In the brain, CNTF is expressed in astrocytes in the neurogenic niches [145], while its receptor, CNTFR $\alpha$, is expressed predominantly in neural progenitor cells and hippocampal neurons, and various other areas of the brain including motor cortex and cerebellum [142, 145]. Overall, CNTF is the most extensively studied neuropoetic cytokine, and its neuroprotective effects are well established [146]. CNTF administration has been shown to alleviate cognitive impairment and to stabilize synaptic protein levels in a transgenic mouse model of AD [111].

\section{Neurotrophic factor small-molecule mimetics for the treatment of Alzheimer's disease}

The therapeutic usage of neurotrophic factors such as BDNF and CNTF in AD patients is hindered by limited blood-brain barrier (BBB) permeability, poor plasma stability and unsuitable pharmacokinetics, and unwanted systemic effects [113, 147-149]. The recombinant BDNF or CNTF in clinical trials have shown limited bioavailability and multiple adverse effects $[150,151]$. A promising strategy to bypass these limitations to develop neurotrophic factors based drugs for $\mathrm{AD}$ which has emerged during the last decade or so is to develop small-molecule mimetics that could exert the therapeutic beneficial effects of neurotrophic factors on neurogenesis, neuronal and synaptic plasticity, and ultimately cognition, with suitable pharmacokinetics and central nervous system (CNS) penetration for drug development, and without unwanted systemic effects produced by the full-length native molecules [148, 149, 152-156]. A major problem associated with the therapeutic usage of whole molecule neurotrophic factors is the pleiotropic actions that derive from their concomitant binding to multiple receptors [154]. The small-molecule mimetics might also allow to modulate various aspects of these signaling pathways in ways that are distinct from the whole molecule neurotrophic factors [154]. By departing from conventional neurotrophic factor signaling, these small-molecule mimetics might provide a novel therapeutic approach to treat AD [154].

Early attempts to develop small-molecule mimetics of neurotrophic factors focused on synthesizing peptidergic compounds consisting of amino acids residues corresponding to various NGF domains [154]. The first small peptide molecule corresponding to an NGF domain demonstrated to exert a neurotrophic effect was the cyclized dimeric form of peptide P7 (amino acid residues, KGKE) which acted through $\mathrm{p} 75^{\mathrm{NTR}}$ receptor [157]. The NGF small peptide mimetics containing KGKE or a homologous sequence have been reported to block $A \beta$ binding to $\mathrm{p} 75^{\mathrm{NTR}}$ and protect against A $\beta$-induced cell death [158]. Another NGF small peptide mimetic, compound D3, which corresponds to amino acid side chains of NGF $\beta$-turn loops and acts through TrkA receptor, has been shown to rescue basal forebrain cholinergic neurodegeneration and spatial reference memory in aged rats [159]. Also, the administration of compound D3 via intracerebroventricular mini pump in J20 mice, which carry APP Swedish and Indiana mutations, has been shown to rescue learning and short-term memory deficits [160].

Small-molecule modulation of BDNF receptor, TrkB, for the treatment of neurodegenerative disorders including $\mathrm{AD}$, has been the focus of intense research in recent years $[113,154,161]$. A naturally occurring flavone, 7,8-dihydroxyflavone (7,8-DHF), which can induce the phosphorylation of $\operatorname{TrkB}$ and its downstream mediators, AKT and ERK, has been shown to be neuroprotective and neurotrophic [161-163]. In studies employing transgenic mouse models of $\mathrm{AD}, 7,8-\mathrm{DHF}$ has shown beneficial effect on learning and memory [164-166]. R7, a prodrug of 7,8-DHF, with considerably improved potency and favorable pharmacokinetics, is 
currently in preclinical development for the treatment of AD [167]. A BDNF small-molecule mimetic compound, LM22A-4, identified using in silico screening with a BDNF loop-domain pharmacophore, was found to promote survival of hippocampal neurons ( $85 \%$ of the efficacy of BDNF), induce TrkB phosphorylation, and prevent neuronal death in an in vitro model of $A D$ [168]. Other TrkB small molecule mimetics that have shown promise in preclinical studies include de-oxygedunin [169], $\mathrm{N}$-acetylserotonin [170], adenosine 2A receptor agonist [171, 172], and BDNF loop mimetics [173, 174]. Recently, our lab also identified BDNF tetrapeptides (peptide B1-B5) which can modulate TrkB signaling and exert neurotrophic effect in mouse hippocampal primary neuronal cultures [175].

A p $75^{\text {NTR }}$ small-molecule non-peptide mimetic identified through in silico screening, LM11A-31, also known as C31, is a highly promising AD drug candidate [154]. LM11A-31 has been shown to block $A \beta$-induced deleterious signaling, including the activation of calpain-Cdk5, GSK-3 $\beta$, and c-jun N-terminal kinase (JNK) signaling, and reduce $A \beta$-induced tau hyperphosphorylation and the inactivation of AKT and cAMP-response element-binding protein (CREB) [176]. LM11A-31 has also been reported to exert beneficial effect both at early and late stages of the AD-like neuropathology in transgenic mice $[177,178]$. LM11A-31, has successfully completed a Phase I clinical trial without any significant adverse effects, and is currently undergoing Phase IIa clinical trial in human AD patients.

Neurotrophic factor small-molecule mimetics offer several advantages as compared to native neurotrophic factor molecules including suitable pharmacokinetics and enhanced BBB permeability for drug development. However, there are certain limitations such as insufficient receptor specificity, requirement for continuous dosing, and effects which are not brain region-specific [154]. These limitations need to be taken into consideration for neurotrophic factor small-molecule mimetics based drugs [154].

\section{CNTF small-molecule peptide mimetic, P021, as a drug candidate for Alzheimer's disease}

As mentioned before, the neuroprotective effects of CNTF are well established [146], and it has been reported to rescue cognitive dysfunction in $\mathrm{AD}$ transgenic mice [111]. However, like other neurotrophic factors, the

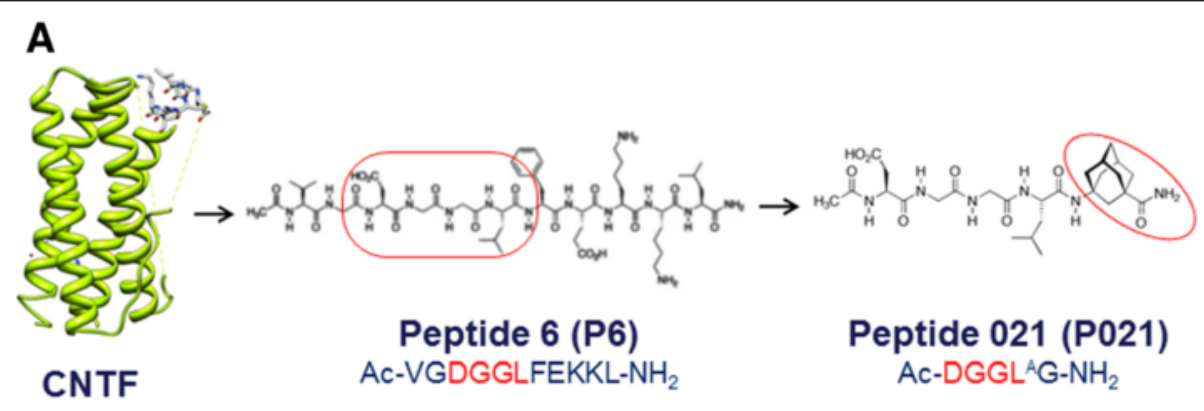

B

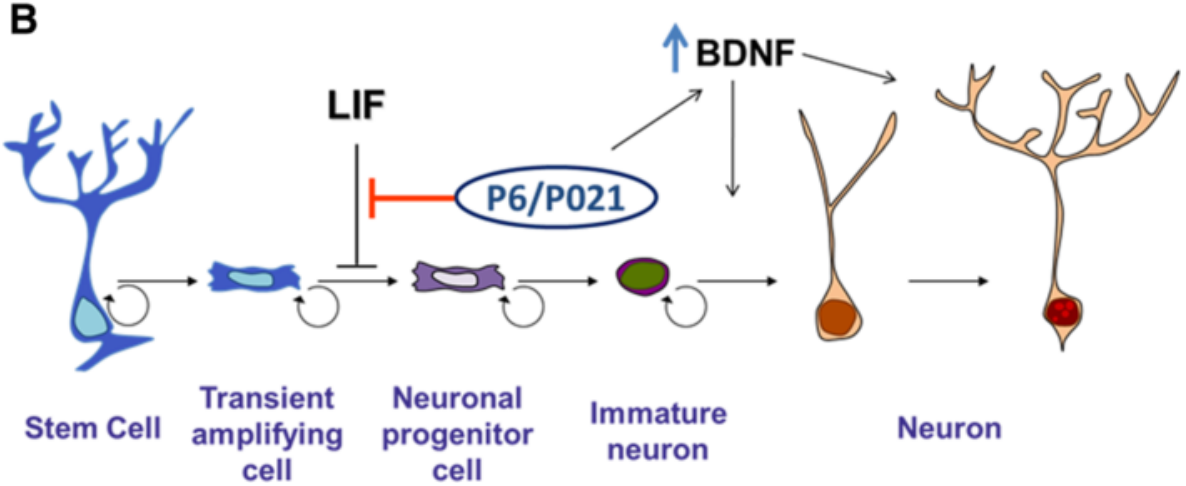

Fig. 4 Design and structures of CNTF small-molecule mimetics and their mechanism of action to enhance formation of NPCs and mature neurons. a Protein Data Base rendering of one 4-helix bundle of truncated human CNTF (Residues 2-187), generated from CNTF. Only one protein chain is shown for clarity. Residues 149GGLFEKKL156 are shown as a tube model, while the rest of the sequence are presented as ribbon [98]. The structures of P6 and P021 are also shown. From the neurogenic 11-mer, Ac-VGDGGLFEKKL-NH 2 (P6), a truncated, still neurogenic pentamer, with an adamantylated glycine group (red oval), Ac-DGGLA -NH $(P 021)$ was designed [191]. b P6 and P021 enhance neural progenitor cells (NPCs) formation and maturation and integration of new-born neurons by competitively inhibiting the LIF signaling and increasing BDNF expression respectively [99, 180, 181, 191, 192] 


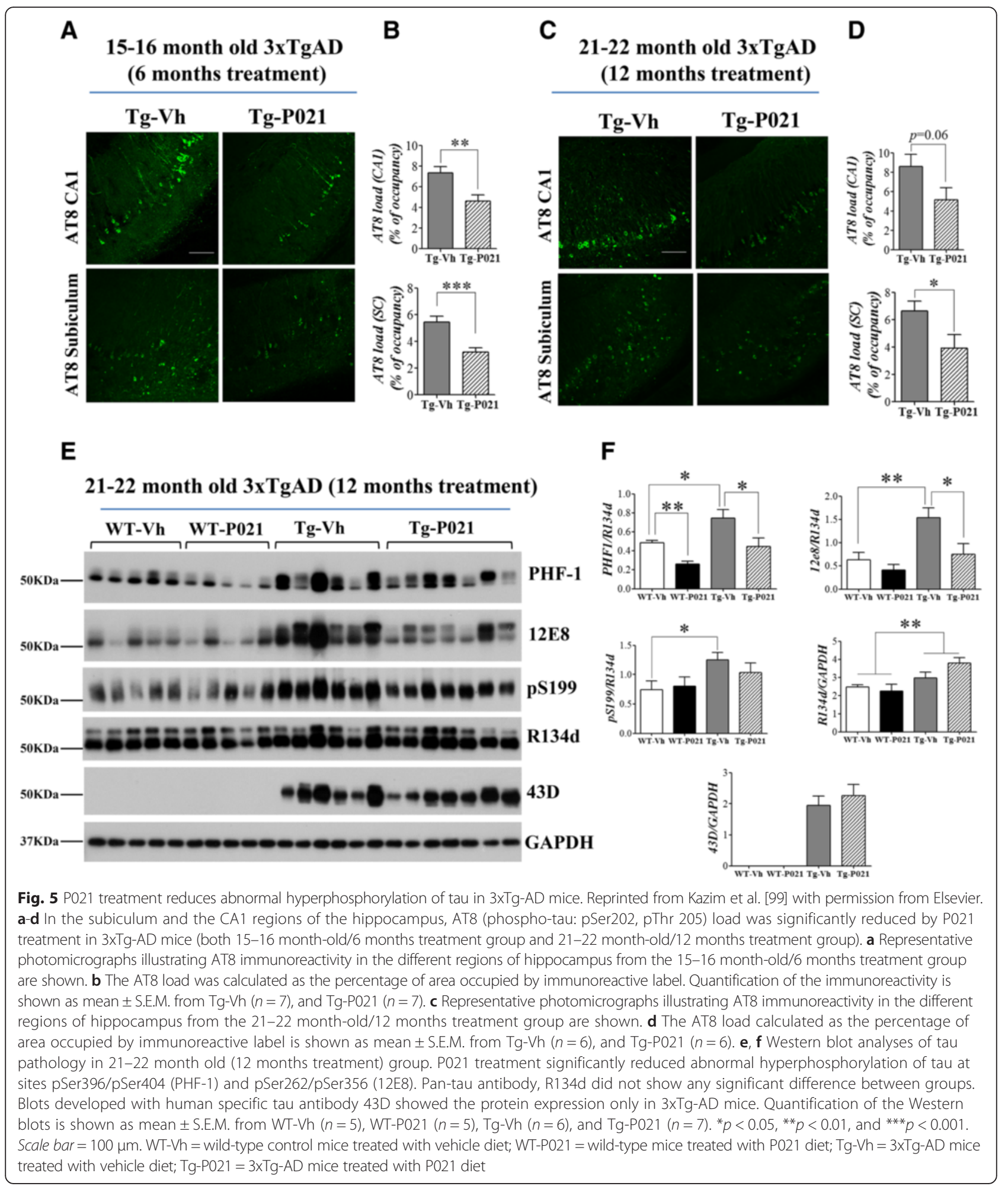

clinical therapeutic usage of CNTF is restricted due to its short plasma half-life and severe adverse effects including anorexia, skeletal muscle loss, muscle pain and cramps, and hyperalgesia, experienced upon peripheral administration in humans [150].
Our laboratory generated an 11-mer CNTF smallmolecule peptide mimetic, Peptide 6 (P6; Ac-VGDGGL FEKKL-NH ${ }_{2}$ ), which corresponds to a biologically active region (amino acid residues 146-156) of human CNTF and was identified using epitope mapping and employing 


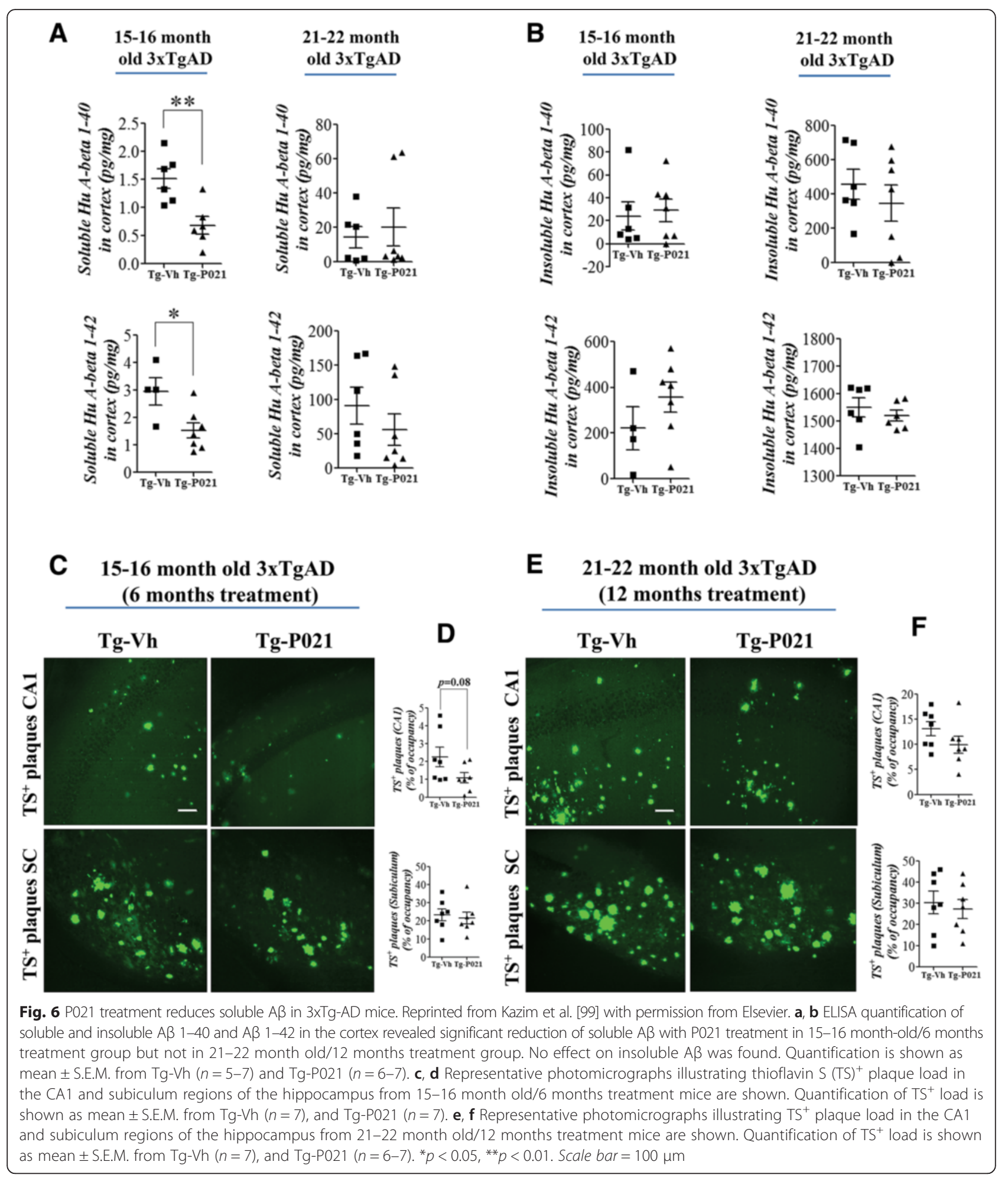

neutralizing antibodies (Fig. 4) [179, 180]. P6 has a plasma half-life of over $6 \mathrm{~h}$ as compared to $\sim 3 \mathrm{~min}$ plasma halflife of recombinant CNTF, and is BBB permeable [180]. P6 acts by competitively inhibiting the LIF signaling, thus promoting the formation of neural precursor cells (NPCs), and by increasing BDNF mRNA levels, thus increasing the survival, maturation, and integration of new-born cells (Fig. 4) $[180,181]$. Peripheral administration of P6 for 30 days via a subcutaneously implanted slow release bolus, was found to enhance dentate gyrus neurogenesis, 
A

15-16 month old 3xTgAD (6 months treatment)
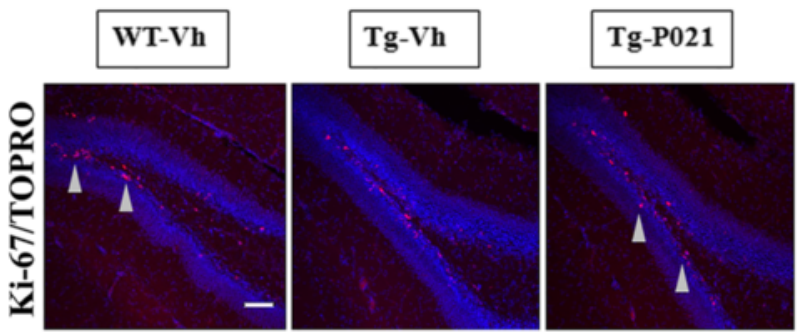

C

15-16 month old 3xTgAD (6 months treatment)
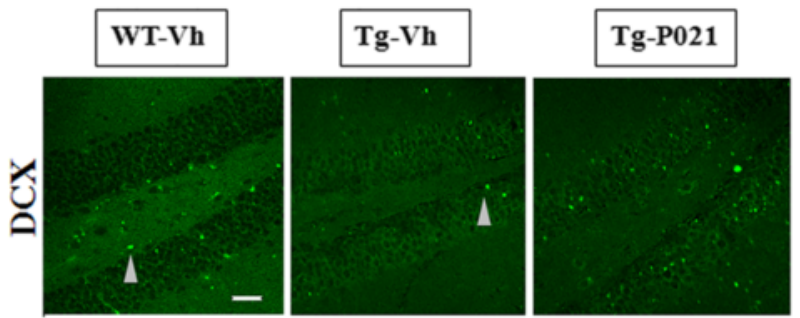

E

15-16 month old 3xTgAD (6 months treatment)
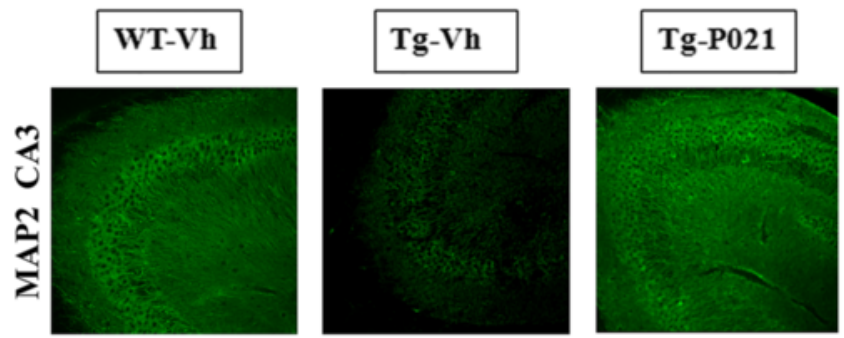

G 15-16 month old 3xTgAD (6 months treatment)
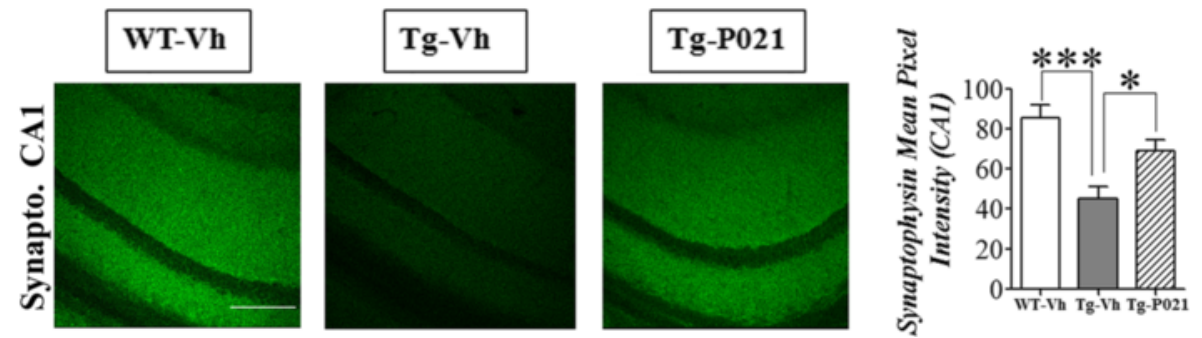

Fig. 7 P021 treatment enhances dentate gyrus neurogenesis and rescues dendritic and synaptic loss in 3xTg-AD mice. Reprinted from Kazim et al. [99] with permission from Elsevier. a-d DG neurogenesis, as evaluated by counting Ki-67 (cell proliferation maker) and doublecortin (DCX, marker for immature neurons) positive cells, was significantly deficient in 15-16 month-old 3XTg-AD mice, and was corrected by P021 treatment. a, c Representative photomicrographs illustrating Ki-67+/TOPRO and doublecortin (DCX) + cells in the DG of hippocampus from 15-16 month-old/6 months treatment mice. $\mathbf{b}$, $\mathbf{d}$ Densitometric quantification data of Ki-67+ and DCX+ cells are shown as mean \pm S.E.M. from WT-Vh ( $(n=6), \operatorname{Tg}-\mathrm{Vh}(n=7)$ and Tg-P021 $(n=7)$, and WT-Vh $(n=5), \operatorname{Tg}-\mathrm{Vh}(n=6)$, and Tg-P021 $(n=6)$, respectively. Arrow heads indicate positive cells. e-h The 15-16 month old 3xTg-AD mice showed significantly reduced MAP2 (dendritic marker) and synaptophysin (presynaptic marker) expression level (fluorescence intensity) in the CA3 and CA1 regions of the hippocampus, respectively. P021 treatment significantly ameliorated this deficit. e Representative photomicrographs illustrating MAP2 immunoreactivity in the CA3 region. $\mathbf{f}$ Densitometric quantification of the immunohistochemistry is shown as mean \pm S.E.M. fromWT-Vh $(n=6), \operatorname{Tg}-\mathrm{Vh}(n=7)$, and Tg-P021 $(n=7)$. g Representative photomicrographs illustrating synaptophysin immunoreactivity in the CA1 region. $\mathbf{h}$ Densitometric quantification of the immunohistochemistry is shown as mean \pm S.E.M. from WT-Vh $(n=6), \mathrm{Tg}-\mathrm{Vh}(n=6)$, and Tg-P021 $(n=6) .{ }^{*} p<0.05,{ }^{* *} p<0.01$, and ${ }^{* * *} p<0.001$. Scale bar $=100 \mu \mathrm{m}$ 


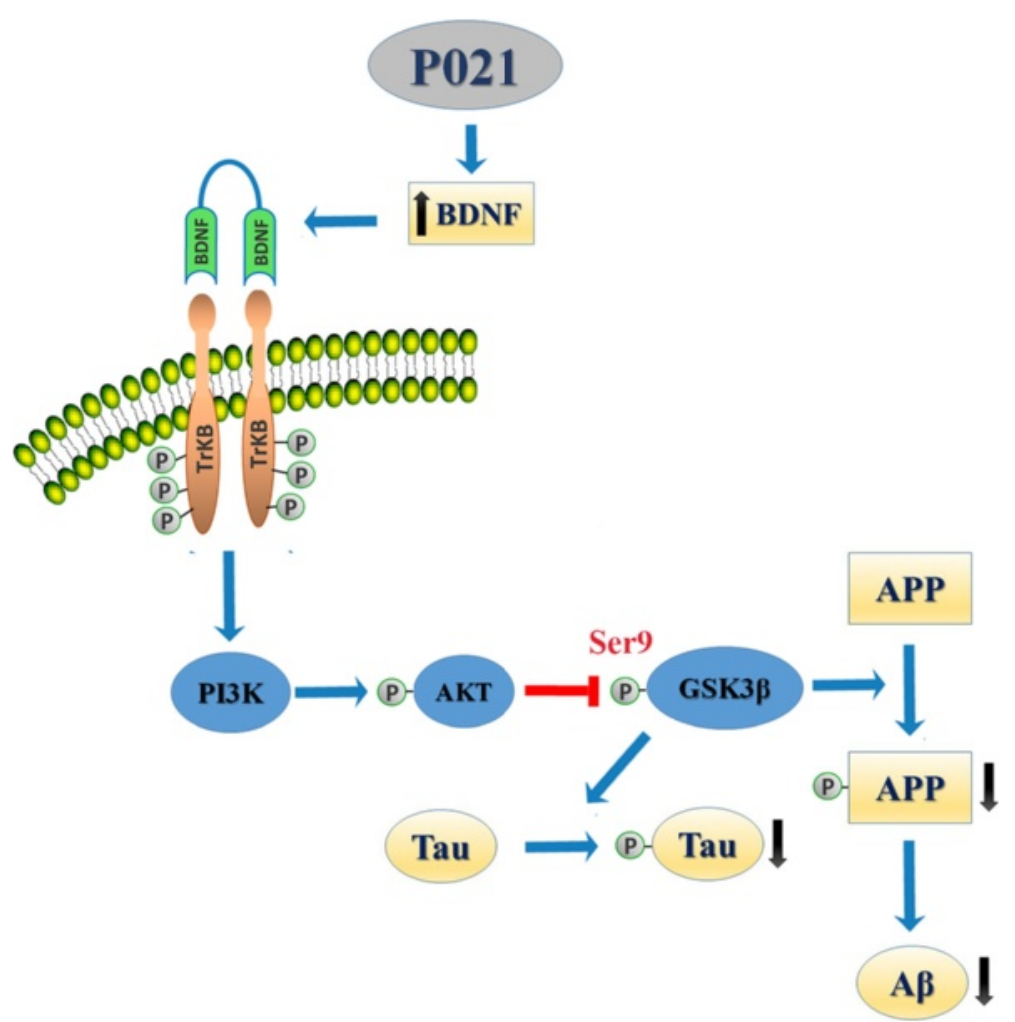

Fig. 8 Mechanism of the disease-modifying effect of P021 in AD. The CNTF small-molecule peptide mimetic compound, P021, increases BDNF expression which via the TrkB-PI3K-AKT pathway leads to inhibitory phosphorylation of GSK3 $\beta$ at Ser9 [99]. GSK3 $\beta$ is major tau kinase and contributes to abnormal hyperphosphorylation of tau at several major sites, and also plays a role in the amyloidogenic processing of APP. P021, via decreasing the GSK3 $\beta$ activity, causes decrease in tau and A $\beta$ pathologies

neuronal plasticity, and spatial memory of the normal adult C57Bl/6 mice [180]. The intraperitoneal administration of P6 for six weeks in 6-7 month-old 3xTg-AD mice (at early stages of the $\mathrm{AD}$ pathology prior to $\mathrm{A} \beta$ plaques and neurofibrillary tangle-like pathology) ameliorated impairment in spatial reference memory and short-term episodic memory by enhancing dentate gyrus neurogenesis and neuronal plasticity in these mice [98]. The 3xTg-AD mice carry AD-related mutation including human PS1 M146V, human APP Swedish, and human tau P301L [182], and develop $A \beta$ plaques and neurofibrillary tanglelike pathologies in a progressive and age-dependent manner, starting at $\sim 9$ and $\sim 12$ months respectively but show cognitive impairment as early as $3-5$ months of age [182-185]. P6 treatment in 6-7 month-old 3xTg-AD mice could not exert any effect on $A \beta$ and tau pathologies [98], seen in this age mice as intraneuronal $A \beta$ accumulation and tau hyperphosphorylation, and not as plaques and tangles [87, 183]. Other preclinical studies employing P6 showed neurogenic and neurotrophic effects in animal models of sporadic AD [181], familial AD [186], Down syndrome [187], autism [188], and traumatic brain injury [189].
To increase the "drug-like" pharmacokinetic properties, we narrowed down the minimal active region of P6 to 4 amino acid residues (Ac-DGGL-NH $\mathrm{N}_{2}$, Peptide 6c, P6c) which could still exert neurogenic and neurotrophic effects [190]. We subsequently added adamantylated glycine group to $\mathrm{P} 6 \mathrm{c}$ to enhance its $\mathrm{BBB}$ permeability, and the resultant pentamer (Ac-DGGL ${ }^{\mathrm{A}} \mathrm{G}-\mathrm{NH}_{2}$ ), called Peptide 021 (P021) (Fig. 4), was found to enhance proliferation and differentiation of adult hippocampal progenitors, increase synaptic markers expression, and improve cognition in C57Bl/6 mice [191]. Oral administration of the compound P021 could rescue cognitive aging by enhancing neurogenesis via increased BDNF expression and by decreasing tau levels in aged Fisher rats [192, 193].

In a recent study, we treated $3 \times \mathrm{Tg}-\mathrm{AD}$ mice with P021 in diet $(60 \mathrm{nmol} / \mathrm{g}$ feed $)$ starting at $9-10$ months of age (early-moderate stages of the AD-like neuropathology) for 12 months, and evaluated the therapeutic effect of the compound at 15-16 months of age (moderate-severe pathology) and at 21-22 months of age (severe pathology) [99]. P021 treatment significantly reduced tau pathology both at moderate and severe stages of the pathology in 3xTg-AD mice (Fig. 5), however, the effect of P021 on A $\beta$ 
pathology was limited to a significant decrease in soluble $A \beta$ levels and a trend towards reduction in $A \beta$ plaque load in $C A 1$ region of hippocampus, consistent with reduction in $A \beta$ generation and not clearance (Fig. 6) [99]. P021 treatment also rescued cognitive impairment, enhanced dentate gyrus neurogenesis, and ameliorated synaptic deficit at moderate to severe stage of the pathology in 3xTg-AD mice (Fig. 7). The effect of P021 on tau and probably also on $A \beta$ pathology was via increased BDNF expression mediated activation of TrkB-PI3K-AKT signaling pathway which leads to down-stream inhibition of GSK-3 $\beta$ activity by increase in its inhibitory phosphorylation at Ser9 by AKT (Fig. 8) [99, 194]. GSK3 $\beta$ is a major tau serine/threonine kinase which is known to phosphorylate tau at many different sites including Ser199, Ser202, Thr205, Ser396, and Ser404 [52, 53]. Reduction in GSK3 $\beta$ activity has also been demonstrated to ameliorate $A \beta$ pathology via reduction in amyloidogenic processing of APP $[195,196]$.

The compound P021 has favorable pharmacokinetics for drug development including plasma half-life of $>3 \mathrm{~h}$ and stability of $>95 \%$ and $>90 \%$ in artificial intestinal fluid up till $2 \mathrm{~h}$ and in artificial gastric juice up till 30 min, respectively, and is BBB permeable [99]. Up to 1 year of P021 administration did not induce any adverse effect in 3xTg-AD mice or in wild type control [99].

\section{Conclusions}

$\mathrm{AD}$ is a multifactorial and heterogeneous devastating neurodegenerative disorder which contributes significantly to health care burden worldwide, more so because of the lack of an effective therapy. Independent of the various etiopathogenic mechanisms involved in $\mathrm{AD}$, the neurogenic and synaptic failure are a common feature of $\mathrm{AD}$ that play a pivotal role in cognitive dysfunction. The rationale for the use of neurotrophic factors based approach is quite strong by virtue of their well-established proneurogenic effects and synaptic repair potential. However, the unfavorable pharmacokinetics, poor brain penetration, and undesired adverse effects associated with the native neurotrophic factor molecules limit their clinical usage. Neurotrophic factor small-molecule mimetics offer a highly promising strategy to overcome these limitations for AD drug development. Preclinical studies have demonstrated therapeutic beneficial effects of several neurotrophic factor small-molecule mimetics particularly the BDNF and CNTF mimetics. These compounds are currently undergoing or will undergo in near-future human clinical trials to assess their therapeutic efficacy in human AD patients. Overall, the neurotrophic factor small-molecule mimetics based neuroregeneration and synaptic repair represents a highly promising therapeutic strategy for $\mathrm{AD}$, and can lead to the development of an effective drug to rescue cognitive impairment.

\section{Abbreviations}

3xTg-AD, triple transgenic Alzheimer's disease mice; 7,8-DHF, 7,8-dihydroxyflavone: Ach, acetylcholine; AD, Alzheimer's disease; APOE $\varepsilon 4$, apolipoprotein E $\varepsilon 4$; APP, amyloid $\beta$ precursor protein; ARTN, artemin; $A \beta$, amyloid $\beta ; B B B$, blood-brain barrier; $\mathrm{BDNF}$, brain-derived neurotrophic factor; BMP, bone morphogenic protein; CaMKII, calcium/calmodulin activated protein kinase II; Cdk5, cyclin-dependent kinase 5; CERAD, consortium to establish a Registry for Alzheimer's disease; ChAT, choline acetyltransferase; CNS, central nervous system; CNTF, ciliary neurotrophic factor; CNTFRa, ciliary neurotrophic factor receptor a; CTF $\beta$, C-terminal fragment $\beta$; ERK, extracellular signal-regulated kinase; FGF2, fibroblast growth factor 2; GDNF, glial cell-derived neurotrophic factor; GFL, glial cell-derived neurotrophic factor family ligands; GFRa, glial cell-derived neurotrophic factor family receptor alpha; gp130, glycoprotein 130; GSK-3ß, glycogen synthase kinase 3 ß; IL-11, interleukin-11; IL-6, interleukin-6; LIF, leukemia inhibitory factor; LIFR, leukemia inhibitory factor $\beta$ receptor; LTP, long-term potentiation; MAP, microtubule associated protein; MAPK, mitogen-activated protein kinase; $\mathrm{MCl}$, mild cognitive impairment; NFTs, neurofibrillary tangles; NGF, nerve growth factor; NPCs, neural precursor cells; NRTN, neurturin; NT3, neurotrophin 3; NT4, neurotrophin 4; P021, peptide 021; P6, peptide 6; P75 NTR, p75 neurotrophin receptor; PI3K, phosphoinositide 3-kinase; PKB/AKT, protein kinase B; PP2A, protein phosphatase 2A; PS1, presenilin 1; PS2, presenilin 2; pSer, phosphorylated serine; PSPN, persephin; pTau, abnormally hyperphosphorylated tau protein; pThr, phosphorylated threonine; RET, rearranged during transfection; TGF $\beta$, tansforming growth factor $\beta$; Trk, tropomysin receptor kinase.

\section{Acknowledgements}

The work on neurotrophic factor small-molecule mimetics in our lab was supported by research grants from Alzheimer's Association, USA; Alzheimer's Drug Discovery Foundation (ADDF), USA; and EVER NeuroPharma GmbH, Unterach, Austria, and in part by the New York State Office of People with Developmental Disabilities. SFK is supported by a doctoral fellowship from SUNY Downstate/NYSIBR Program in Developmental Neuroscience.

We would like to acknowledge late Dr. Inge Grundke-labal who initiated the work with neurotrophic factor small-molecule peptide mimetics in our lab. Dr. Grundke-lqbal passed away on September 22, 2012. We would also like to acknowledge Dr. M. Omar Chohan, Dr. Julie Blanchard, Dr. Bin Li, and Dr. Silvia Bolognin who contributed significantly to the work on neurotrophic factor small-molecule mimetics in our lab.

\section{Authors' contributions}

SFK drafted the first version of this review. KI revised the manuscript for intellectual content. All authors read and approved the final manuscript.

\section{Competing interests}

KI has U.S. patents on CNTF small-molecule peptide mimetics for the treatment of $A D$ and related neurodegenerative disorders.

\section{Author details}

'Department of Neurochemistry, and SUNY Downstate/NYSIBR Program in Developmental Neuroscience, New York State Institute for Basic Research (NYSIBR), 1050 Forest Hill Road, Staten Island, NY 10314, USA. ${ }^{2}$ Graduate Program in Neural and Behavioral Science, and Department of Physiology and Pharmacology, State University of New York (SUNY) Downstate Medical Center, 450 Clarkson Avenue, Brooklyn, NY 11203, USA.

Received: 24 April 2016 Accepted: 2 July 2016

Published online: 11 July 2016

\section{References}

1. Ballard C, Gauthier S, Corbett A, Brayne C, Aarsland D, Jones E. Alzheimer's disease. Lancet. 2011;377:1019-31.

2. Cornutiu G. The epidemiological scale of Alzheimer's disease. J Clin Med Res. 2015;7:657-66.

3. Hebert LE, Weuve J, Scherr PA, Evans DA. Alzheimer disease in the United States (2010-2050) estimated using the 2010 census. Neurology. 2013;80:1778-83.

4. Alzheimer's A. Alzheimer's disease facts and figures. Alzheimers Dement. 2016;2016:12

5. Prince MJ, Guerchet MM, Prina M. The Epidemiology and Impact of Dementia: Current State and Future Trends. WHO Thematic Briefing. Geneva; World Health Organization. 2015. APA citation can be accessed at: (https://kclpure.kcl. 
ac.uk/portal/en/publications/the-epidemiology-and-impact-ofdementia(538a75cb-1519-49d4-8876-92ae9cfc4151)/export.html)

6. Iqbal K, Grundke-lqbal I. Opportunities and challenges in developing Alzheimer disease therapeutics. Acta Neuropathol. 2011;122:543-9.

7. Hebert LE, Scherr PA, Bienias JL, Bennett DA, Evans DA. Alzheimer disease in the US population: prevalence estimates using the 2000 census. Arch Neurol. 2003;60:1119-22.

8. Prince $M$, Guerchet, M, Prina, M. Policy Brief for Heads of Government: The Global Impact of Dementia 2013-2050. London: Alzheimer's Disease Internationall; 2013. APA citation can be accessed at: (https://kclpure.kcl. ac.uk/portal/en/publications/the-global-impact-of-dementia20132050(893055ed-e533-4d88-9d15-3aa4abdfcc20)/export.html).

9. $\quad$ Burns A, lliffe S. Alzheimer's disease. BMJ. 2009;338:b158.

10. Cummings JL. Alzheimer's disease. N Engl J Med. 2004;351:56-67.

11. Grady CL, Haxby JV, Horwitz B, Sundaram M, Berg G, Schapiro M, Friedland RP, Rapoport SI. Longitudinal study of the early neuropsychological and cerebral metabolic changes in dementia of the Alzheimer type. J Clin Exp Neuropsychol. 1988;10:576-96

12. Glenner GG, Wong CW. Alzheimer's disease: initial report of the purification and characterization of a novel cerebrovascular amyloid protein. Biochem Biophys Res Commun. 1984;120:885-90.

13. Grundke-lqbal I, lqbal K, Tung YC, Quinlan M, Wisniewski HM, Binder LI. Abnormal phosphorylation of the microtubule-associated protein tau (tau) in Alzheimer cytoskeletal pathology. Proc Natl Acad Sci U S A. 1986;83:4913-7.

14. Crews L, Masliah E. Molecular mechanisms of neurodegeneration in Alzheimer's disease. Hum Mol Genet. 2010;19:R12-20.

15. Davies $C A$, Mann DM, Sumpter $P Q$, Yates PO. A quantitative morphometric analysis of the neuronal and synaptic content of the frontal and temporal cortex in patients with Alzheimer's disease. J Neurol Sci. 1987;78:151-64.

16. Demars M, Hu YS, Gadadhar A, Lazarov O. Impaired neurogenesis is an early event in the etiology of familial Alzheimer's disease in transgenic mice. J Neurosci Res. 2010;88:2103-17.

17. Li B, Yamamori H, Tatebayashi Y, Shafit-Zagardo B, Tanimukai H, Chen S, lqbal K, Grundke-lqbal I. Failure of neuronal maturation in Alzheimer disease dentate gyrus. J Neuropathol Exp Neurol. 2008;67:78-84.

18. Mu Y, Gage FH. Adult hippocampal neurogenesis and its role in Alzheimer's disease. Mol Neurodegeneration. 2011;6:85.

19. Scheff SW, Price DA. Alzheimer's disease-related alterations in synaptic density: neocortex and hippocampus. J Alzheimers Dis. 2006;9:101-15.

20. Scheff SW, Price DA, Schmitt FA, DeKosky ST, Mufson EJ. Synaptic alterations in CA1 in mild Alzheimer disease and mild cognitive impairment. Neurology. 2007;68:1501-8.

21. Scheff SW, Price DA, Schmitt FA, Mufson EJ. Hippocampal synaptic loss in early Alzheimer's disease and mild cognitive impairment. Neurobiol Aging. 2006:27:1372-84.

22. Selkoe DJ. Alzheimer's disease is a synaptic failure. Science. 2002;298:789-91.

23. Shruster A, Melamed E, Offen D. Neurogenesis in the aged and neurodegenerative brain. Apoptosis. 2010;15:1415-21.

24. Sze Cl, Troncoso JC, Kawas C, Mouton P, Price DL, Martin LJ. Loss of the presynaptic vesicle protein synaptophysin in hippocampus correlates with cognitive decline in Alzheimer disease. J Neuropathol Exp Neurol. 1997;56:933-44

25. Terry RD, Masliah E, Salmon DP, Butters N, DeTeresa R, Hill R, Hansen LA, Katzman R. Physical basis of cognitive alterations in Alzheimer's disease: synapse loss is the major correlate of cognitive impairment. Ann Neurol. 1991;30:572-80

26. Aimone JB, Deng W, Gage FH. Adult neurogenesis: integrating theories and separating functions. Trends Cogn Sci. 2010;14:325-37.

27. Aimone JB, Wiles J, Gage FH. Potential role for adult neurogenesis in the encoding of time in new memories. Nat Neurosci. 2006;9:723-7.

28. Deng W, Aimone JB, Gage FH. New neurons and new memories: how does adult hippocampal neurogenesis affect learning and memory? Nat Rev Neurosci. 2010;11:339-50.

29. Neves G, Cooke SF, Bliss TV. Synaptic plasticity, memory and the hippocampus: a neural network approach to causality. Nat Rev Neurosci. 2008;9:65-75.

30. Sahay A, Scobie KN, Hill AS, O'Carroll CM, Kheirbek MA, Burghardt NS, Fenton AA, Dranovsky A, Hen R. Increasing adult hippocampal neurogenesis is sufficient to improve pattern separation. Nature. 2011;472:466-70.

31. Battaglia F, Wang HY, Ghilardi MF, Gashi E, Quartarone A, Friedman E, Nixon RA. Cortical plasticity in Alzheimer's disease in humans and rodents. Biol Psychiatry. 2007:62:1405-12.
32. Arendt T. Synaptic degeneration in Alzheimer's disease. Acta Neuropathol. 2009;118:167-79.

33. DeKosky ST, Scheff SW. Synapse loss in frontal cortex biopsies in Alzheimer's disease: correlation with cognitive severity. Ann Neurol. 1990;27:457-64.

34. DeKosky ST, Scheff SW, Styren SD. Structural correlates of cognition in dementia: quantification and assessment of synapse change. Neurodegeneration. 1996;5:417-21.

35. Masliah E, Mallory M, Hansen L, DeTeresa R, Alford M, Terry R. Synaptic and neuritic alterations during the progression of Alzheimer's disease. Neurosci Lett. 1994;174:67-72.

36. Iqbal K, Kazim SF, Bolognin S, Blanchard J. Shifting balance from neurodegeneration to regeneration of the brain: a novel therapeutic approach to Alzheimer's disease and related neurodegenerative conditions. Neural Regen Res. 2014;9:1518-9.

37. About a peculiar disease of the cerebral cortex. By Alois Alzheimer, 1907 (Translated by L. Jarvik and H. Greenson). Alzheimer disease and associated disorders 1987, 1:3-8

38. Iqbal K, Grundke-lqbal I. Alzheimer's disease, a multifactorial disorder seeking multitherapies. Alzheimers Dement. 2010;6:420-4.

39. Bird TD. Genetic aspects of Alzheimer disease. Genet Med. 2008;10:231-9.

40. Guerreiro R, Hardy J. Genetics of Alzheimer's disease. Neurotherapeutics. 2014;11:732-7.

41. Corder EH, Saunders AM, Strittmatter WJ, Schmechel DE, Gaskell PC, Small GW, Roses AD, Haines JL, Pericak-Vance MA. Gene dose of apolipoprotein E type 4 allele and the risk of Alzheimer's disease in late onset families. Science. 1993; 261:921-3.

42. Hardy JA, Higgins GA. Alzheimer's disease: the amyloid cascade hypothesis. Science. 1992;256:184-5.

43. Kang J, Lemaire HG, Unterbeck A, Salbaum JM, Masters CL, Grzeschik KH, Multhaup G, Beyreuther K, Muller-Hill B. The precursor of Alzheimer's disease amyloid A4 protein resembles a cell-surface receptor. Nature. 1987;325:733-6.

44. Masters CL, Simms G, Weinman NA, Multhaup G, McDonald BL, Beyreuther K. Amyloid plaque core protein in Alzheimer disease and down syndrome. Proc Natl Acad Sci U S A. 1985;82:4245-9.

45. Lambert MP, Barlow AK, Chromy BA, Edwards C, Freed R, Liosatos M, Morgan TE, Rozovsky I, Trommer B, Viola KL, et al. Diffusible, nonfibrillar ligands derived from Abeta1-42 are potent central nervous system neurotoxins. Proc Natl Acad Sci U S A. 1998;95:6448-53.

46. Walsh DM, Klyubin I, Fadeeva JV, Cullen WK, Anwyl R, Wolfe MS, Rowan MJ, Selkoe DJ. Naturally secreted oligomers of amyloid beta protein potently inhibit hippocampal long-term potentiation in vivo. Nature. 2002;416:535-9.

47. Bliss TV, Collingridge GL. A synaptic model of memory: long-term potentiation in the hippocampus. Nature. 1993:361:31-9.

48. Wisniewski KE, Dalton AJ, McLachlan C, Wen GY, Wisniewski HM. Alzheimer's disease in down's syndrome: clinicopathologic studies. Neurology. 1985;35:957-61.

49. Karlinsky H. Alzheimer's disease in down's syndrome. A review J Am Geriatr Soc. 1986;34:728-34.

50. Grundke-lqbal I, Iqbal K, Quinlan M, Tung YC, Zaidi MS, Wisniewski HM. Microtubule-associated protein tau. A component of Alzheimer paired helical filaments. J Biol Chem. 1986;261:6084-9. (http://www.ncbi.nlm.nih. gov/pubmed/3331112), PMID: 3331112. It's an English translation of original case by Alois Alzheimer.

51. Iqbal K, Wisniewski HM, Shelanski ML, Brostoff S, Liwnicz BH, Terry RD. Protein changes in senile dementia. Brain Res. 1974;77:337-43.

52. Wang JZ, Grundke-lqbal I, lqbal K. Kinases and phosphatases and tau sites involved in Alzheimer neurofibrillary degeneration. Eur J Neurosci. 2007;25: 59-68.

53. Wang JZ, Wu Q, Smith A, Grundke-lqbal I, Iqbal K. Tau is phosphorylated by GSK-3 at several sites found in Alzheimer disease and its biological activity markedly inhibited only after it is prephosphorylated by A-kinase. FEBS Lett. 1998;436:28-34.

54. Iqbal K, Alonso Adel C, Chen S, Chohan MO, El-Akkad E, Gong CX, Khatoon S, Li B, Liu F, Rahman A, et al. Tau pathology in Alzheimer disease and other tauopathies. Biochim Biophys Acta. 2005;1739:198-210.

55. Gong CX, Shaikh S, Wang JZ, Zaidi T, Grundke-lqbal I, Iqbal K. Phosphatase activity toward abnormally phosphorylated tau: decrease in Alzheimer disease brain. J Neurochem. 1995;65:732-8.

56. Gong CX, Singh TJ, Grundke-lqbal I, Iqbal K. Phosphoprotein phosphatase activities in Alzheimer disease brain. J Neurochem. 1993;61:921-7. 
57. Liu F, Grundke-lqbal I, lqbal K, Gong CX. Contributions of protein phosphatases PP1, PP2A, PP2B and PP5 to the regulation of tau phosphorylation. Eur J Neurosci. 2005;22:1942-50.

58. Nelson PT, Alafuzoff I, Bigio EH, Bouras C, Braak H, Cairns NJ, Castellani RJ, Crain BJ, Davies P, Del Tredici K, et al. Correlation of Alzheimer disease neuropathologic changes with cognitive status: a review of the literature. J Neuropathol Exp Neurol. 2012;71:362-81.

59. Braak H, Del Tredici K. The pathological process underlying Alzheimer's disease in individuals under thirty. Acta Neuropathol. 2011;121:171-81.

60. Braak H, Thal DR, Ghebremedhin E, Del Tredici K. Stages of the pathologic process in Alzheimer disease: age categories from 1 to 100 years. J Neuropathol Exp Neurol. 2011;70:960-9.

61. Riley KP, Jicha GA, Davis D, Abner EL, Cooper GE, Stiles N, Smith CD, Kryscio RJ, Nelson PT, Van Eldik $\sqcup$, Schmitt FA. Prediction of preclinical Alzheimer's disease: longitudinal rates of change in cognition. J Alzheimers Dis. 2011;25:707-17.

62. Schmitt FA, Davis DG, Wekstein DR, Smith CD, Ashford JW, Markesbery WR. Preclinical" AD revisited: neuropathology of cognitively normal older adults. Neurol. 2000;55:370-6.

63. Webster SJ, Bachstetter AD, Nelson PT, Schmitt FA, Van Eldik LJ. Using mice to model Alzheimer's dementia: an overview of the clinical disease and the preclinical behavioral changes in ten mouse models. Frontiers in Genetics. 2014,5:88

64. Belleville S, Sylvain-Roy S, de Boysson C, Menard MC. Characterizing the memory changes in persons with mild cognitive impairment. Prog Brain Res. 2008;169:365-75.

65. Khan UA, Liu L, Provenzano FA, Berman DE, Profaci CP, Sloan R, Mayeux R, Duff KE, Small SA. Molecular drivers and cortical spread of lateral entorhinal cortex dysfunction in preclinical Alzheimer's disease. Nat Neurosci. 2014;17:304-11.

66. Liu L, Drouet V, Wu JW, Witter MP, Small SA, Clelland C, Duff K. Transsynaptic spread of tau pathology in vivo. PLoS One. 2012;7:e31302.

67. Reitz C, Brickman AM, Brown TR, Manly J, DeCarli C, Small SA, Mayeux R. Linking hippocampal structure and function to memory performance in an aging population. Arch Neurol. 2009;66:1385-92.

68. Small SA. Isolating pathogenic mechanisms embedded within the hippocampal circuit through regional vulnerability. Neuron. 2014;84:32-9.

69. Collie A, Maruff P. The neuropsychology of preclinical Alzheimer's disease and mild cognitive impairment. Neurosci Biobehav Rev. 2000;24:365-74.

70. Smith GE, Pankratz VS, Negash S, Machulda MM, Petersen RC, Boeve BF, Knopman DS, Lucas JA, Ferman TJ, Graff-Radford N, Ivnik RJ. A plateau in preAlzheimer memory decline: evidence for compensatory mechanisms? Neurology. 2007;69:133-9.

71. Bondi MW, Jak AJ, Delano-Wood L, Jacobson MW, Delis DC, Salmon DP. Neuropsychological contributions to the early identification of Alzheimer's disease. Neuropsychol Rev. 2008;18:73-90.

72. Storandt M, Grant EA, Miller JP, Morris JC. Longitudinal course and neuropathologic outcomes in original vs revised $\mathrm{MCl}$ and in pre-MCl. Neurology. 2006;67:467-73.

73. Twamley EW, Ropacki SA, Bondi MW. Neuropsychological and neuroimaging changes in preclinical Alzheimer's disease. J Int Neuropsychol Soc. 2006;12:707-35.

74. Tuokko H, Morris C, Ebert P. Mild cognitive impairment and everyday functioning in older adults. Neurocase. 2005;11:40-7.

75. McKhann GM, Knopman DS, Chertkow H, Hyman BT, Jack Jr CR, Kawas CH, Klunk WE, Koroshetz WJ, Manly JJ, Mayeux R, et al. The diagnosis of dementia due to Alzheimer's disease: recommendations from the National Institute on Aging-Alzheimer's association workgroups on diagnostic guidelines for Alzheimer's disease. Alzheimers Dement. 2011;7:263-9.

76. Bruel-Jungerman E, Rampon C, Laroche S. Adult hippocampal neurogenesis, synaptic plasticity and memory: facts and hypotheses. Rev Neurosci. 2007; 18:93-114.

77. Abrous DN, Wojtowicz JM. Interaction between neurogenesis and hippocampal memory system: New Vistas. Cold Spring Harb Perspect Biol. 2015;7.

78. Drapeau E, Mayo W, Aurousseau C, Le Moal M, Piazza PV, Abrous DN. Spatial memory performances of aged rats in the water maze predict levels of hippocampal neurogenesis. Proc Natl Acad Sci U S A. 2003;100:14385-90.

79. Dupret D, Revest JM, Koehl M, Ichas F, De Giorgi F, Costet P, Abrous DN, Piazza PV. Spatial relational memory requires hippocampal adult neurogenesis. PLoS One. 2008;3:e1959.

80. Leuner B, Gould E, Shors TJ. Is there a link between adult neurogenesis and learning? Hippocampus. 2006;16:216-24.

81. Lledo PM, Alonso M, Grubb MS. Adult neurogenesis and functional plasticity in neuronal circuits. Nat Rev Neurosci. 2006;7:179-93.
82. Deng W, Saxe MD, Gallina IS, Gage FH. Adult-born hippocampal dentate granule cells undergoing maturation modulate learning and memory in the brain. J Neurosci. 2009;29:13532-42.

83. Shors TJ. From stem cells to grandmother cells: how neurogenesis relates to learning and memory. Cell Stem Cell. 2008;3:253-8.

84. Phillips W, Michell AW, Barker RA. Neurogenesis in diseases of the central nervous system. Stem Cells Dev. 2006;15:359-79.

85. Bonfanti $L$, Peretto P. Adult neurogenesis in mammals-a theme with many variations. Eur J Neurosci. 2011;34:930-50.

86. Gage FH. Neurogenesis in the adult brain. J Neurosci. 2002;22:612-3.

87. Inokuchi K. Adult neurogenesis and modulation of neural circuit function. Curr Opin Neurobiol. 2011;21:360-4.

88. Kempermann G, Gage FH. Neurogenesis in the adult hippocampus. Novartis Found Symp. 2000;231:220-35. discussion 235-241, 302-226.

89. Li Y, Mu Y, Gage FH. Development of neural circuits in the adult hippocampus. Curr Top Dev Biol. 2009;87:149-74.

90. Grote HE, Hannan AJ. Regulators of adult neurogenesis in the healthy and diseased brain. Clin Exp Pharmacol Physiol. 2007;34:533-45.

91. Verret L, Jankowsky JL, Xu GM, Borchelt DR, Rampon C. Alzheimer's-type amyloidosis in transgenic mice impairs survival of newborn neurons derived from adult hippocampal neurogenesis. J Neurosci. 2007;27:6771-80.

92. Verret L, Trouche S, Zerwas M, Rampon C. Hippocampal neurogenesis during normal and pathological aging. Psychoneuroendocrinology. 2007;32 Suppl 1:S26-30.

93. Jin K, Galvan V, Xie L, Mao XO, Gorostiza OF, Bredesen DE, Greenberg DA. Enhanced neurogenesis in Alzheimer's disease transgenic (PDGF-APPSW, Ind) mice. Proc Natl Acad Sci U S A. 2004;101:13363-7.

94. Knobloch M, Mansuy IM. Dendritic spine loss and synaptic alterations in Alzheimer's disease. Mol Neurobiol. 2008:37:73-82.

95. Scheff SW, DeKosky ST, Price DA. Quantitative assessment of cortical synaptic density in Alzheimer's disease. Neurobiol Aging. 1990;11:29-37.

96. Scheff SW, Price DA. Synaptic pathology in Alzheimer's disease: a review of ultrastructural studies. Neurobiol Aging. 2003;24:1029-46.

97. van Praag H, Schinder AF, Christie BR, Toni N, Palmer TD, Gage FH. Functional neurogenesis in the adult hippocampus. Nature. 2002;415:1030-4

98. Blanchard J, Wanka L, Tung YC, Cardenas-Aguayo Mdel C, LaFerla FM, lqbal K, Grundke-lqbal I. Pharmacologic reversal of neurogenic and neuroplastic abnormalities and cognitive impairments without affecting Abeta and tau pathologies in 3xTg-AD mice. Acta Neuropathol. 2010;120:605-21.

99. Kazim SF, Blanchard J, Dai CL, Tung YC, LaFerla FM, labal IG, labal K. Disease modifying effect of chronic oral treatment with a neurotrophic peptidergic compound in a triple transgenic mouse model of Alzheimer's disease. Neurobiol Dis. 2014;71:110-30.

100. Chevallier NL, Soriano S, Kang DE, Masliah E, Hu G, Koo EH. Perturbed neurogenesis in the adult hippocampus associated with presenilin-1 A246E mutation. Am J Pathol. 2005;167:151-9.

101. Dong H, Goico B, Martin M, Csernansky CA, Bertchume A, Csernansky JG. Modulation of hippocampal cell proliferation, memory, and amyloid plaque deposition in APPsw (Tg2576) mutant mice by isolation stress. Neurosci. 2004;127:601-9.

102. Donovan MH, Yazdani U, Norris RD, Games D, German DC, Eisch AJ. Decreased adult hippocampal neurogenesis in the PDAPP mouse model of Alzheimer's disease. J Comp Neurol. 2006;495:70-83.

103. Wang JM, Singh C, Liu L, Irwin RW, Chen S, Chung EJ, Thompson RF, Brinton $\mathrm{RD}$. Allopregnanolone reverses neurogenic and cognitive deficits in mouse model of Alzheimer's disease. Proc Natl Acad Sci U S A. 2010;107:6498-503.

104. Wen PH, Hof PR, Chen X, Gluck K, Austin G, Younkin SG, Younkin LH, DeGasperi R, Gama Sosa MA, Robakis NK, et al. The presenilin-1 familial Alzheimer disease mutant P117L impairs neurogenesis in the hippocampus of adult mice. Exp Neurol. 2004;188:224-37.

105. Enciu AM, Nicolescu MI, Manole CG, Muresanu DF, Popescu LM, Popescu BO. Neuroregeneration in neurodegenerative disorders. BMC Neurol. 2011;11:75.

106. Hunsberger JG, Rao M, Kurtzberg J, Bulte JW, Atala A, LaFerla FM, Greely HT, Sawa A, Gandy S, Schneider LS, Doraiswamy PM. Accelerating stem cell trials for Alzheimer's disease. Lancet Neurol 2015. doi: 10.1016/S1474-4422(15)00332-4.

107. Tang J. How close is the stem cell cure to the Alzheimer's disease: Future and beyond? Neural Regen Res. 2012;7:66-71.

108. Blurton-Jones M, Kitazawa M, Martinez-Coria H, Castello NA, Muller FJ, Loring JF, Yamasaki TR, Poon WW, Green KN, LaFerla FM. Neural stem cells improve cognition via BDNF in a transgenic model of Alzheimer disease. Proc Natl Acad Sci U S A. 2009;106:13594-9. 
109. Kiyota $\mathrm{T}$, Ingraham $\mathrm{KL}$, Jacobsen MT, Xiong H, Ikezu T. FGF2 gene transfer restores hippocampal functions in mouse models of Alzheimer's disease and has therapeutic implications for neurocognitive disorders. Proc Natl Acad Sci U S A. 2011;108:E1339-48.

110. Nagahara AH, Merrill DA, Coppola G, Tsukada S, Schroeder BE, Shaked GM, Wang L, Blesch A, Kim A, Conner JM, et al. Neuroprotective effects of brainderived neurotrophic factor in rodent and primate models of Alzheimer's disease. Nat Med. 2009;15:331-7.

111. Garcia P, Youssef I, Utvik JK, Florent-Bechard S, Barthelemy V, Malaplate-Armand C, Kriem B, Stenger C, Koziel V, Olivier JL, et al. Ciliary neurotrophic factor cell-based delivery prevents synaptic impairment and improves memory in mouse models of Alzheimer's disease. J Neurosci. 2010;30:7516-27.

112. Barbacid M. Neurotrophic factors and their receptors. Curr Opin Cell Biol. 1995;7:148-55

113. Lu B, Nagappan G, Guan X, Nathan PJ, Wren P. BDNF-based synaptic repair as a disease-modifying strategy for neurodegenerative diseases. Nat Rev Neurosci. 2013;14:401-16.

114. Semkova I, Krieglstein J. Neuroprotection mediated via neurotrophic factors and induction of neurotrophic factors. Brain Res Brain Res Rev. 1999;30:176-88.

115. Chao MV. Neurotrophins and their receptors: a convergence point for many signalling pathways. Nat Rev Neurosci. 2003;4:299-309.

116. Hock C, Heese K, Hulette C, Rosenberg C, Otten U. Region-specific neurotrophin imbalances in Alzheimer disease: decreased levels of brain-derived neurotrophic factor and increased levels of nerve growth factor in hippocampus and cortical areas. Arch Neurol. 2000;57:846-51.

117. Lee J, Fukumoto H, Orne J, Klucken J, Raju S, Vanderburg CR, Irizarry MC, Hyman BT, Ingelsson M. Decreased levels of BDNF protein in Alzheimer temporal cortex are independent of BDNF polymorphisms. Exp Neurol. 2005:194:91-6.

118. Michalski B, Fahnestock M. Pro-brain-derived neurotrophic factor is decreased in parietal cortex in Alzheimer's disease. Brain Res Mol Brain Res. 2003;111:148-54.

119. Phillips HS, Hains JM, Armanini M, Laramee GR, Johnson SA, Winslow JW. BDNF mRNA is decreased in the hippocampus of individuals with Alzheimer's disease. Neuron. 1991;7:695-702.

120. Lee J, Duan W, Mattson MP. Evidence that brain-derived neurotrophic factor is required for basal neurogenesis and mediates, in part, the enhancement of neurogenesis by dietary restriction in the hippocampus of adult mice. J Neurochem. 2002;82:1367-75.

121. Vilar M, Mira H. Regulation of neurogenesis by neurotrophins during adulthood: expected and unexpected roles. Front Neurosci. 2016;10:26.

122. Ji Y, Lu Y, Yang F, Shen W, Tang TT, Feng L, Duan S, Lu B. Acute and gradual increases in BDNF concentration elicit distinct signaling and functions in neurons. Nat Neurosci. 2010;13:302-9.

123. Kang $H$, Schuman EM. Long-lasting neurotrophin-induced enhancement of synaptic transmission in the adult hippocampus. Science. 1995;267:1658-62.

124. Korte M, Kang H, Bonhoeffer T, Schuman E. A role for BDNF in the late-phase of hippocampal long-term potentiation. Neuropharmacol. 1998;37:553-9.

125. Lu Y, Christian K, Lu B. BDNF: a key regulator for protein synthesis-dependent LTP and long-term memory? Neurobiol Learn Mem. 2008;89:312-23.

126. Scott SA, Mufson EJ, Weingartner JA, Skau KA, Crutcher KA. Nerve growth factor in Alzheimer's disease: increased levels throughout the brain coupled with declines in nucleus basalis. J Neurosci. 1995;15:6213-21.

127. Francis PT, Palmer AM, Snape M, Wilcock GK. The cholinergic hypothesis of Alzheimer's disease: a review of progress. J Neurol Neurosurg Psychiatry. 1999;66:137-47.

128. Iulita MF, Cuello AC. Nerve growth factor metabolic dysfunction in Alzheimer's disease and down syndrome. Trends Pharmacol Sci. 2014;35:338-48.

129. Olson L. NGF and the treatment of Alzheimer's disease. Exp Neurol. 1993;124:5-15.

130. Tuszynski MH, Yang JH, Barba D, HS U, Bakay RA, Pay MM, Masliah E, Conner JM, Kobalka P, Roy S, Nagahara AH. Nerve growth factor gene therapy: activation of neuronal responses in alzheimer disease. JAMA Neurol. 2015; 72:1139-47.

131. Airaksinen MS, Saarma M. The GDNF family: signalling, biological functions and therapeutic value. Nat Rev Neurosci. 2002;3:383-94.

132. Konishi Y, Yang LB, He P, Lindholm K, Lu B, Li R, Shen Y. Deficiency of GDNF receptor GFRalpha1 in Alzheimer's neurons results in neuronal death. J Neurosci. 2014;34:13127-38.

133. Revilla S, Ursulet S, Alvarez-Lopez MJ, Castro-Freire M, Perpina U, Garcia-Mesa Y, Bortolozzi A, Gimenez-Llort L, Kaliman P, Cristofol R, et al. Lenti-GDNF gene therapy protects against Alzheimer's disease-like neuropathology in 3xTg-AD mice and MC65 cells. CNS Neurosci Ther. 2014;20:961-72.

134. Ip NY. The neurotrophins and neuropoietic cytokines: two families of growth factors acting on neural and hematopoietic cells. Ann N Y Acad Sci. 1998;840:97-106.

135. Stolp HB. Neuropoietic cytokines in normal brain development and neurodevelopmental disorders. Mol Cell Neurosci. 2013;53:63-8.

136. Adachi T, Takanaga H, Kunimoto M, Asou H. Influence of LIF and BMP-2 on differentiation and development of glial cells in primary cultures of embryonic rat cerebral hemisphere. J Neurosci Res. 2005;79:608-15.

137. Kasai M, Satoh K, Akiyama T. Wnt signaling regulates the sequential onset of neurogenesis and gliogenesis via induction of BMPs. Genes Cells. 2005;10:777-83.

138. Rowitch $\mathrm{DH}$, Kriegstein AR. Developmental genetics of vertebrate glial-cell specification. Nature. 2010;468:214-22.

139. Senaldi G, Varnum BC, Sarmiento U, Starnes C, Lile J, Scully S, Guo J, Elliott G, McNinch J, Shaklee CL, et al. Novel neurotrophin-1/B cell-stimulating factor-3: a cytokine of the IL-6 family. Proc Natl Acad Sci U S A. 1999;96:11458-63.

140. Shi Y, Wang W, Yourey PA, Gohari S, Zukauskas D, Zhang J, Ruben S, Alderson RF. Computational EST database analysis identifies a novel member of the neuropoietic cytokine family. Biochem Biophys Res Commun. 1999;262:132-8.

141. Ding J, He Z, Ruan J, Ma Z, Liu Y, Gong C, lqbal K, Sun S, Chen H. Role of ciliary neurotrophic factor in the proliferation and differentiation of neural stem cells. J Alzheimers Dis. 2013;37:587-92.

142. Emsley JG, Hagg T. Endogenous and exogenous ciliary neurotrophic factor enhances forebrain neurogenesis in adult mice. Exp Neurol. 2003;183:298-310.

143. Yang P, Arnold SA, Habas A, Hetman M, Hagg T. Ciliary neurotrophic factor mediates dopamine D2 receptor-induced CNS neurogenesis in adult mice. J Neurosci. 2008:28:2231-41.

144. Davis S, Aldrich TH, Stahl N, Pan L, Taga T, Kishimoto T, Ip NY, Yancopoulos GD. LIFR beta and gp130 as heterodimerizing signal transducers of the tripartite CNTF receptor. Science. 1993;260:1805-8

145. Sendtner M, Carroll P, Holtmann B, Hughes RA, Thoenen H. Ciliary neurotrophic factor. J Neurobiol. 1994;25:1436-53.

146. Pasquin S, Sharma M, Gauchat JF. Ciliary neurotrophic factor (CNTF): New facets of an old molecule for treating neurodegenerative and metabolic syndrome pathologies. Cytokine Growth Factor Rev. 2015;26(5):507-15.

147. Chen ZY, Cao L, Wang LM, Guo C, Ye JL, Chai YF, Yan ZY. Development of neurotrophic molecules for treatment of neurodegeneration. Curr Protein Pept Sci. 2001;2:261-76.

148. Longo FM, Yang T, Knowles JK, Xie Y, Moore LA, Massa SM. Small molecule neurotrophin receptor ligands: novel strategies for targeting Alzheimer's disease mechanisms. Curr Alzheimer Res. 2007;4:503-6.

149. Massa SM, Xie Y, Longo FM. Alzheimer's therapeutics: neurotrophin domain small molecule mimetics. J Mol Neurosci. 2003;20:323-6.

150. ACTSG. A double-blind placebo-controlled clinical trial of subcutaneous recombinant human ciliary neurotrophic factor (rHCNTF) in amyotrophic lateral sclerosis. ALS CNTF Treatment Study Group. Neurology. 1996;46:1244-9.

151. Ochs G, Penn RD, York M, Giess R, Beck M, Tonn J, Haigh J, Malta E, Traub M, Sendtner M, Toyka KV. A phase I/II trial of recombinant methionyl human brain derived neurotrophic factor administered by intrathecal infusion to patients with amyotrophic lateral sclerosis. Amyotroph Lateral Scler Other Motor Neuron Disord. 2000;1:201-6.

152. Longo FM, Massa SM. Neurotrophin-based strategies for neuroprotection. J Alzheimers Dis. 2004;6:S13-7.

153. Longo FM, Massa SM. Neurotrophin receptor-based strategies for Alzheimer's disease. Curr Alzheimer Res. 2005;2:167-9.

154. Longo FM, Massa SM. Small-molecule modulation of neurotrophin receptors: a strategy for the treatment of neurological disease. Nat Rev Drug Discov. 2013:12:507-25

155. Massa SM, Xie Y, Longo FM. Alzheimer's therapeutics: neurotrophin small molecule mimetics. J Mol Neurosci. 2002;19:107-11.

156. Xie Y, Longo FM. Neurotrophin small-molecule mimetics. Prog Brain Res. 2000;128:333-47.

157. Longo FM, Manthorpe M, Xie YM, Varon S. Synthetic NGF peptide derivatives prevent neuronal death via a p75 receptor-dependent mechanism. J Neurosci Res. 1997:48:1-17.

158. Yaar M, Zhai S, Panova I, Fine RE, Eisenhauer PB, Blusztajn JK, Lopez-Coviella I, Gilchrest BA. A cyclic peptide that binds p75(NTR) protects neurones from 
beta amyloid (1-40)-induced cell death. Neuropathol Appl Neurobiol. 2007; 33:533-43.

159. Bruno MA, Clarke PB, Seltzer A, Quirion R, Burgess K, Cuello AC, Saragovi HU. Long-lasting rescue of age-associated deficits in cognition and the CNS cholinergic phenotype by a partial agonist peptidomimetic ligand of TrkA. J Neurosci. 2004;24:8009-18.

160. Aboulkassim T, Tong XK, Tse YC, Wong TP, Woo SB, Neet KE, Brahimi F, Hamel E, Saragovi HU. Ligand-dependent TrkA activity in brain differentially affects spatial learning and long-term memory. Mol Pharmacol. 2011;80: 498-508.

161. Zeng Y, Wang X, Wang Q, Liu S, Hu X, McClintock SM. Small molecules activating TrkB receptor for treating a variety of CNS disorders. CNS Neurol Disord Drug Targets. 2013;12:1066-77.

162. Jang SW, Liu X, Yepes M, Shepherd KR, Miller GW, Liu Y, Wilson WD, Xiao G, Blanchi B, Sun YE, Ye K. A selective TrkB agonist with potent neurotrophic activities by 7,8-dihydroxyflavone. Proc Natl Acad Sci U S A. 2010;107:2687-92.

163. Liu X, Obianyo O, Chan CB, Huang J, Xue S, Yang JJ, Zeng F, Goodman M, Ye K. Biochemical and biophysical investigation of the brain-derived neurotrophic factor mimetic 7,8-dihydroxyflavone in the binding and activation of the TrkB receptor. J Biol Chem. 2014;289:27571-84.

164. Castello NA, Nguyen MH, Tran JD, Cheng D, Green KN, LaFerla FM. 7,8Dihydroxyflavone, a small molecule TrkB agonist, improves spatial memory and increases thin spine density in a mouse model of Alzheimer disease-like neuronal loss. PLoS One. 2014;9:e91453.

165. Chen C, Li XH, Zhang S, Tu Y, Wang YM, Sun HT. 7,8-dihydroxyflavone ameliorates scopolamine-induced Alzheimer-like pathologic dysfunction. Rejuvenation Res. 2014;17:249-54.

166. Zhang Z, Liu X, Schroeder JP, Chan CB, Song M, Yu SP, Weinshenker D, Ye K. 7,8-dihydroxyflavone prevents synaptic loss and memory deficits in a mouse model of Alzheimer's disease. Neuropsychopharmacology. 2014;39: $638-50$

167. Liu C, Chan CB, Ye K. 7,8-dihydroxyflavone, a small molecular TrkB agonist, is useful for treating various BDNF-implicated human disorders. Transl Neurodegeneration. 2016;5:2.

168. Massa SM, Yang T, Xie Y, Shi J, Bilgen M, Joyce JN, Nehama D, Rajadas J, Longo FM. Small molecule BDNF mimetics activate TrkB signaling and prevent neuronal degeneration in rodents. J Clin Invest. 2010;120:1774-85.

169. Jang SW, Liu X, Chan CB, France SA, Sayeed I, Tang W, Lin X, Xiao G, Andero $R$, Chang $Q$, et al. Deoxygedunin, a natural product with potent neurotrophic activity in mice. PLoS One. 2010;5:e11528.

170. Jang SW, Liu X, Pradoldej S, Tosini G, Chang Q, luvone PM, Ye K. $\mathrm{N}$-acetylserotonin activates TrkB receptor in a circadian rhythm. Proc Natl Acad Sci U S A. 2010;107:3876-81.

171. Lee FS, Chao MV. Activation of Trk neurotrophin receptors in the absence of neurotrophins. Proc Natl Acad Sci U S A. 2001;98:3555-60.

172. Lee FS, Rajagopal R, Kim AH, Chang PC, Chao MV. Activation of Trk neurotrophin receptor signaling by pituitary adenylate cyclase-activating polypeptides. J Biol Chem. 2002;277:9096-102.

173. Fletcher JM, Hughes RA. Novel monocyclic and bicyclic loop mimetics of brain-derived neurotrophic factor. J Pept Sci. 2006;12:515-24.

174. O'Leary PD, Hughes RA. Design of potent peptide mimetics of brain-derived neurotrophic factor. J Biol Chem. 2003;278:25738-44.

175. Cardenas-Aguayo Mdel C, Kazim SF, Grundke-labal I, labal K. Neurogenic and neurotrophic effects of BDNF peptides in mouse hippocampal primary neuronal cell cultures. PLoS One. 2013;8:e53596.

176. Yang T, Knowles JK, Lu Q, Zhang H, Arancio O, Moore LA, Chang T, Wang Q, Andreasson K, Rajadas J, et al. Small molecule, non-peptide p75 ligands inhibit Abeta-induced neurodegeneration and synaptic impairment. PLoS One. 2008:3:e3604.

177. Knowles JK, Simmons DA, Nguyen TV, Vander Griend L, Xie Y, Zhang H, Yang T, Pollak J, Chang T, Arancio O, et al. Small molecule p75NTR ligand prevents cognitive deficits and neurite degeneration in an Alzheimer's mouse model. Neurobiol Aging. 2013;34:2052-63.

178. Simmons DA, Knowles JK, Belichenko NP, Banerjee G, Finkle C, Massa SM, Longo FM. A small molecule P75NTR ligand, LM1 1A-31, reverses cholinergic neurite dystrophy in Alzheimer's disease mouse models with mid- to latestage disease progression. PLoS One. 2014;9:e102136.

179. Chen H, Tung YC, Li B, labal K, Grundke-labal I. Trophic factors counteract elevated FGF-2-induced inhibition of adult neurogenesis. Neurobiol Aging 2007;28:1148-62.
180. Chohan MO, Li B, Blanchard J, Tung YC, Heaney AT, Rabe A, labal K, Grundkelqbal I. Enhancement of dentate gyrus neurogenesis, dendritic and synaptic plasticity and memory by a neurotrophic peptide. Neurobiol Aging. 2011;32: 1420-34.

181. Bolognin S, Blanchard J, Wang X, Basurto-Islas G, Tung YC, Kohlbrenner E, Grundke-labal I, labal K. An experimental rat model of sporadic Alzheimer's disease and rescue of cognitive impairment with a neurotrophic peptide. Acta Neuropathol. 2012;123:133-51.

182. Oddo S, Caccamo A, Shepherd JD, Murphy MP, Golde TE, Kayed R, Metherate R, Mattson MP, Akbari Y, LaFerla FM. Triple-transgenic model of Alzheimer's disease with plaques and tangles: intracellular Abeta and synaptic dysfunction. Neuron. 2003;39:409-21.

183. Billings LM, Oddo S, Green KN, McGaugh JL, LaFerla FM. Intraneuronal Abeta causes the onset of early Alzheimer's disease-related cognitive deficits in transgenic mice. Neuron. 2005;45:675-88.

184. Davis KE, Eacott MJ, Easton A, Gigg J. Episodic-like memory is sensitive to both Alzheimer's-like pathological accumulation and normal ageing processes in mice. Behav Brain Res. 2013;254:73-82.

185. Stevens LM, Brown RE. Reference and working memory deficits in the 3xTg-AD mouse between 2 and 15-months of age: A cross-sectional study. Behav Brain Res. 2015;278:496-505.

186. Rockenstein E, Ubhi K, Doppler E, Novak P, Moessler H, Li B, Blanchard J, Grundke-lqbal I, lqbal K, Mante M, et al. Regional comparison of the neurogenic effects of CNTF-derived peptides and cerebrolysin in AbetaPP transgenic mice. J Alzheimers Dis. 2011;27:743-52.

187. Blanchard J, Bolognin S, Chohan MO, Rabe A, lqbal K, Grundke-labal I. Rescue of synaptic failure and alleviation of learning and memory impairments in a trisomic mouse model of down syndrome. J Neuropathol Exp Neurol. 2011;70:1070-9.

188. Kazim SF, Cardenas-Aguayo Mdel C, Arif M, Blanchard J, Fayyaz F, Grundke-lqbal I, Iqbal K. Sera from children with autism induce autistic features which can be rescued with a CNTF small peptide mimetic in rats. PLoS One. 2015;10:e0118627.

189. Chohan MO, Bragina O, Kazim SF, Statom G, Baazaoui N, Bragin D, lqbal K, Nemoto $\mathrm{E}$, Yonas $\mathrm{H}$. Enhancement of neurogenesis and memory by a neurotrophic peptide in mild to moderate traumatic brain injury. Neurosurg. 2015;76:201-14. discussion 214-205.

190. Blanchard J, Chohan MO, Li B, Liu F, lqbal K, Grundke-lqbal I. Beneficial effect of a CNTF tetrapeptide on adult hippocampal neurogenesis, neuronal plasticity, and spatial memory in mice. J Alzheimers Dis. 2010;21:1185-95.

191. Li B, Wanka L, Blanchard J, Liu F, Chohan MO, lqbal K, Grundke-lqbal I. Neurotrophic peptides incorporating adamantane improve learning and memory, promote neurogenesis and synaptic plasticity in mice. FEBS Lett. 2010;584:3359-65.

192. Bolognin S, Buffelli M, Puolivali J, lqbal K. Rescue of cognitive-aging by administration of a neurogenic and/or neurotrophic compound. Neurobiol Aging. 2014;35:2134-46.

193. Khatoon S, Chalbot S, Bolognin S, Puolivali J, Iqbal K. Elevated tau level in aged rat cerebrospinal fluid reduced by treatment with a neurotrophic compound. J Alzheimers Dis. 2015:47:557-64.

194. Elliott E, Atlas R, Lange A, Ginzburg I. Brain-derived neurotrophic factor induces a rapid dephosphorylation of tau protein through a PI-3 Kinase signalling mechanism. Eur J Neurosci. 2005;22:1081-9.

195. DaRocha-Souto B, Coma M, Perez-Nievas BG, Scotton TC, Siao M, Sanchez-Ferrer P, Hashimoto T, Fan Z, Hudry E, Barroeta I, et al. Activation of glycogen synthase kinase-3 beta mediates beta-amyloid induced neuritic damage in Alzheimer's disease. Neurobiol Dis. 2012;45: $425-37$.

196. Sereno L, Coma M, Rodriguez M, Sanchez-Ferrer P, Sanchez MB, Gich I, Agullo JM, Perez M, Avila J, Guardia-Laguarta C et al. A novel GSK-3beta inhibitor reduces Alzheimer's pathology and rescues neuronal loss in vivo. Neurobiol Dis. 2009;35:359-67. 